\title{
Sediment contaminant surveillance in Milford Haven Waterway
}

\author{
D. I. Little, B. Bullimore, Y. Galperin and W. J. Langston
}

D. I. Little, Environmental Consultancy, Swavesey, Cambridge CB24 4RL, UK; e-mail: david.i.little@ btinternet.com

B. Bullimore, Deep Green Seas, Marine Environmental Consultancy, Tiers Cross, Haverfordwest SA62 3DG, UK

Y. Galperin, Environmental Geochemistry Consulting, Moorpark, California 93021, USA

W. J. Langston, Marine Biological Association, Citadel Hill, Plymouth PL1 2PB, UK

\begin{abstract}
Sediment contaminants were monitored in Milford Haven Waterway (MHW) since 1978 (hydrocarbons) and 1982 (metals), with the aim of providing surveillance of environmental quality in one of the UK's busiest oil and gas ports. This aim is particularly important during and after large-scale investment in liquefied natural gas (LNG) facilities. However, methods inevitably have changed over the years, compounding the difficulties of coordinating sampling and analytical programmes. After a review by the MHW Environmental Surveillance Group (MHWESG), sediment hydrocarbon chemistry was investigated in detail in 2010. Natural Resources Wales (NRW) contributed their MHW data for 2007 and 2012, collected to assess the condition of the Special Area of Conservation (SAC) designated under the European Union Habitats Directive. Datasets during 2007-2012 have thus been more comparable. The results showed conclusively that a MHW-wide peak in concentrations of sediment polycyclic aromatic hydrocarbons (PAHs), metals and other contaminants occurred in late 2007. This was corroborated by independent annual monitoring at one centrally-located station with peaks in early 2008 and 2011. The spatial and temporal patterns of recovery from the 2007 peak, shown by MHWwide surveys in 2010 and 2012, indicate several probable causes of contaminant trends, as follows: atmospheric deposition, catchment runoff, sediment resuspension from dredging, and construction of two LNG terminals and a power station. Adverse biological effects predictable in 2007 using international sediment quality guidelines, were independently tested by data from monitoring schemes of more than a decade duration in MHW (starfish, limpets), and in the wider SAC (grey seals). Although not proving cause and effect, many of these potential biological receptors showed a simultaneous negative response to the elevated 2007 contamination following intense dredging activity in 2006. Wetland bird counts were typically at a peak in the winter of 2005-2006 previous to peak dredging. In the following winter 2006-2007, shelduck in Pembroke River showed their lowest winter count, and spring 2007 was the largest ever drop in numbers of broods across MHW between successive breeding seasons. Wigeon counts in Pembroke River were again low in late 2012 after further dredging nearby. These results are strongly supported by PAH data reported previously from invertebrate bioaccumulation studies in MHW 2007-2010, themselves closely reflecting sediment trends for PAHs in Pembroke River and Angle Bay.
\end{abstract}

Keywords Biological effects, Construction, Dredging, Environmental Impact Assessment, LNG, Metals, PAHs

\section{Introduction}

Seabed and tidal flat sediments are eroded, transported, sorted and deposited by natural processes of tidal, wind and wave action. New sediment enters Milford Haven Waterway (MHW, Fig. 1) from the catchment, the atmosphere and the sea. Soil has been disturbed by forest clearing and agriculture since pre-historic times (Little 2009). Forestry activities in 2005-2006 in the Eastern Cleddau catchment would have released sediment, but it would mostly have been trapped in two reservoirs without reaching MHW. Both new and reworked sediments are to some degree contaminated. Most of the sediment sources and disturbances in MHW are not well quantified. In terms of detecting impacts, the waterway is not a highly-turbid system (Nelson-Smith 1965). The background suspended particulate matter (SPM) concentrations are between 10-16 mg/l from data obtained using elutriation samplers over numerous tidal cycles at the Valero jetty, upper Pembroke River, and the Milford Haven Port Authority (MHPA) jetty (Little 2009).

Chronic sediment disturbance and resuspension occur by propeller wash and bow-waves of tankers, tugs, ferries, cargo and fishing vessels, by shellfish and bait-digging, and by small vessel mooring. MHW has oil terminals, a ferry terminal, marinas, light industry, tourism, fin- and shell-fisheries (cockles, winkles and native oyster). Major anthropogenic causes of mud resuspension within MHW are periodic dredging and less frequent large-scale engineering projects, of which the liquefied natural gas (LNG)-related projects are the most recent. Demolition of the disused jetty structures, runoff from disturbed land, and pile-driving for the new constructions were sources of sediment resuspension mainly between 2003 and 2005. Disturbance of sediment by the repeated manoeuvring of construction vessels would delay the settling of mud, allowing enhanced entrainment by currents. SPM generated by effluent outfall channel scour, disturbance and spillage during MHPA capital and maintenance dredging operations were likely to have peaked in 2006 and 2010. This is augmented by dredging at Neyland Yacht Haven (NYH) marina, peaking from 2007-2008 and discharging directly off Neyland. 


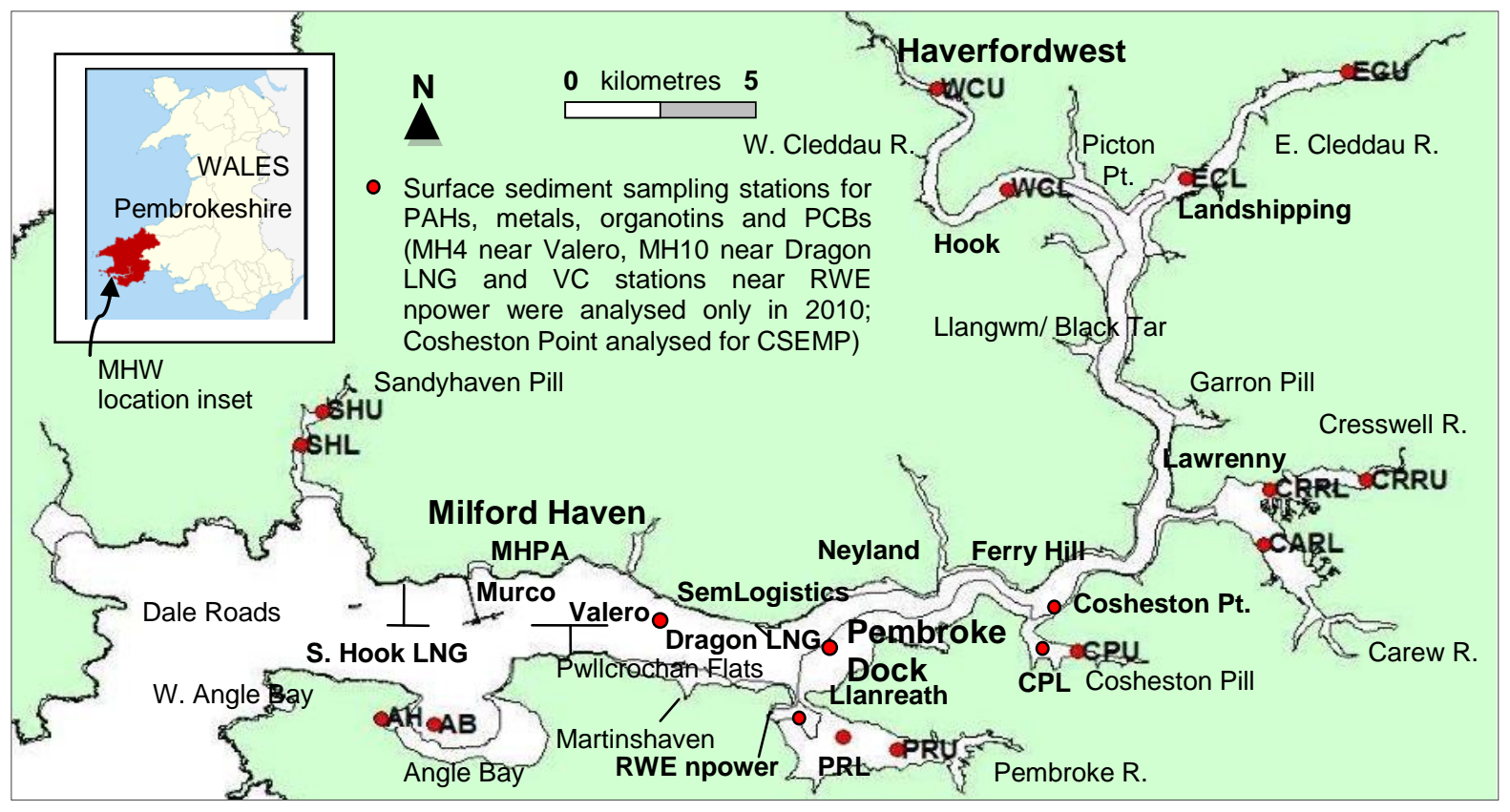

Fig. 1 MHW fine-grained sediment sampling locations 2007, 2010 and 2012 [In 2010, stations SHU, SHL and WCU were not sampled, and metals, organotins and polychlorinated biphenyls (PCBs) were not analysed; see Table 1 for abbreviations]

MHW has been a major oil port since 1960 with up to four refineries, associated jetties and pipelines, and one of the largest UK terminals for crude oil, diesel, gasoline, and jet fuel (SemLogistics). Although only one refinery is now in operation (Valero), over the last decade two new liquefied natural gas plants (Dragon LNG and South Hook LNG) and a large combined cycle gas-turbine power plant (RWE npower) were built (Fig. 1).

The largest oil spill in MHW was 72,000 tonnes (t) of Forties Blend crude oil and $480 \mathrm{t}$ of heavy fuel oil (HFO) after the grounding of 'Sea Empress' in February 1996. At five stations in October 1996 the sediment had a polycyclic aromatic hydrocarbon (PAH) fingerprint reflecting a petrogenic source that was not seen in 1993 before the spill. These stations aligned with flood-tide sediment transport paths on the northern shelf (Little 2009), a finding not highlighted previously (Levell et al. 1997). Sediment contaminants were traced using PAH fingerprints from 2007, 2010 and 2012. 'Sea Empress' HFO was still detectable in 2010, but by now more widely in the lower and mid-MHW as far as inner Cosheston Pill. Upstream from this part of MHW, using source ratios of terpane and sterane biomarkers, it was shown that Iranian crude oil was present in sediments, likely to be from 100 t spilled near Valero in December 1988 by 'El Omar' (Little and Little 1991). Emissions from tankers, the former oil-fired power station and refineries, and fires such as the 1940 air raid at Llanreath tank-farm are significant sources of pyrogenic PAHs mainly via the atmosphere and runoff. These predominantly historical pollution sources are recycled by disturbance of surficial sediment exposing older material (Little et al. 2015).

A surveillance programme coordinated for over 20 years by MHWESG was periodically reviewed by Hobbs and Morgan (1992), Bent (2000), Warwick (2006), Little (2009) and Bullimore (2013). The sediment trend analysis (STA) using early 1980s grain size data has been a good foundation for estuarine research, monitoring and management (McLaren and Little 1987; Little and McLaren 1989; Little and Bullimore 2015). The STA approach integrates all the various sources of sediment over time, using a systematic comparison of sequential changes in grain size distribution collected on a closely-spaced grid. It resolves them on the basis of probable transport pathways to which a significance level can be ascribed. A powerful sequel to this kinematic approach is to assess possible links between candidate contaminant sources, transfer pathways, and potential biological receptors. Such links are central to targeting monitoring and reliable Environmental Impact Assessment (EIA).

Little (2009) summarized the history of industrial and municipal pollution from chronic inputs and accidental releases, and showed evidence of fine-grained sediment mobility affecting the fate of hydrocarbons and metals. This review included the contaminant dataset collected in late 2007 by the former Countryside Council for Wales $\left(\mathrm{CCW}^{1}\right)$. These PAHs and trace metals data showed that international sediment quality guidelines (SQGs; for example 'Effects Range Low', and 'Probable Effects Level') were widely exceeded, although no detailed interpretation was made at the time. The PAHs distribution patterns were compared with some of the earlier MHW data, but the total hydrocarbons (THC) and metals could not be properly compared

\footnotetext{
${ }^{1}$ From April 2013 Natural Resources Wales (NRW) replaced CCW and Environment Agency (EA) Wales.
} 
due to changes in the method used (Little 2009). Another MHWESG study is underway with University of Plymouth and Centre for Environment, Fisheries, and Aquaculture Science (CEFAS) to address the noncomparability of the historical THC and metals analyses.

Two other recommendations by Little (2009) have now been fully implemented by MHWESG: (1) sediment profile imagery (SPI) and sediment plan-views at 550 stations in May 2012 by Germano \& Associates Inc. (2013); and (2) environmental forensics analysis of sources of hydrocarbons at 19 stations in MHW in 2010 using 18 candidate reference samples provided by MHWESG members and Fugro ERT (2012). To complement the second project, MHWESG commissioned further environmental forensics interpretation of the 2010 data. During that study, another dataset collected in late 2012 was provided by NRW during 2013. This enabled a thorough comparison between hydrocarbons and metals data for the years 2007 and 2012 analysed by the National Laboratory Service (NLS) and also the hydrocarbons evaluation of the 2010 samples analysed by Fugro ERT. The newer datasets did not include determination of THC, unlike most of the data since 1978 (Little 2009). The supplemental forensics work for MHWESG was published by Little et al. (2015).

The role of MHW in attracting LNG investment became strategically-important by 2004, when UK ceased to be self-sufficient in natural gas. In the national interest MHW must be kept open and safe for commercial navigation, in a cost-effective and environmentally-sustainable manner (MHPA, 2011). This should be performed in compliance with EIA principles (2011/92/EU) and, in an SAC, with the Habitats Directive (1992). Rostron et al. (1986) were concerned that adequate study of dredging impacts in MHW should be conducted. Morgan et al. (1996) showed that MHWESG data had been useful in understanding potential influences on MHW, including dredging. However, they identified a knowledge gap on the release and impacts of historical pollutants during dredging and other forms of physical disturbance. The aim of the present study is to fill this gap using detailed results of sediment contaminant monitoring, with emphasis on 2007-2012, and to discuss and compare these with results of other independent biology and chemistry surveys. The objectives are to describe spatial and temporal patterns in contaminants, their probable causes including dredging and LNG construction, and their possible effects on a range of potential biological receptors being monitored by other programmes.

\section{Materials and methods}

Field sampling

Sediment samples were surficial sediments $(<2 \mathrm{~cm}$ depth $)$ from grabs or cores using stainless steel (hydrocarbons) or plastic (metals) scoops. Samples from MH4 and MH10 were collected for MHWESG by NRW in April 2010. GTS Subsea (2010) vibracore sampling on 9-10 August 2010 at stations VC23 and 24a/1 in Pennar Gut was for Jacobs on behalf of RWE npower. All other samples were collected by NRW from 3-5 November 2010 (for MHWESG) and in October-November in 2007 and 2012. The station locations, dates, sampling methods and personnel were more comparable than in similar studies at any time in MHW (Table 1).

Table 1 Sediment sampling stations in 2007, 2010 and 2012 (see Fig. 1 for exceptions)

\begin{tabular}{|c|c|c|c|c|}
\hline Station & $\begin{array}{l}\text { \% mud } \\
2007\end{array}$ & $\begin{array}{l}\text { \% mud } \\
2012\end{array}$ & Station location & $\begin{array}{c}\text { Latitude/ longitude, or Ordnance Survey } \\
\text { grid reference }\end{array}$ \\
\hline SHU & 0.50 & $<0.01$ & Sandy Haven Upper & $\mathrm{N} 51.7347^{\circ}, \mathrm{W} 5.0997^{\circ}$ \\
\hline SHL & 3.30 & 6.25 & Sandy Haven Lower & $\mathrm{N} 51.7296^{\circ}, \mathrm{W} 5.1045^{\circ}$ \\
\hline $\mathrm{AH}$ & 70.63 & 87.22 & Angle Harbour & $\mathrm{N} 51.6834^{\circ}, \mathrm{W} 5.831^{\circ}$ \\
\hline $\mathrm{AB}$ & 23.81 & 30.75 & Angle Bay & N 51.6827 ${ }^{\circ}$, W $5.7224^{\circ}$ \\
\hline PRU & 52.39 & 34.04 & Pembroke River Upper & $\mathrm{N} 51.6785^{\circ}, \mathrm{W} 4.9522^{\circ}$ \\
\hline PRL & 85.78 & 80.08 & Pembroke River Lower & N 51.6806, W $4.9659^{\circ}$ \\
\hline $\mathrm{CPU}$ & 85.98 & 81.17 & Cosheston Pill Upper & N $51.6947^{\circ}, \mathrm{W} 4.9063^{\circ}$ \\
\hline CPL & 63.61 & 62.97 & Cosheston Pill Lower & $\mathrm{N} 51.6968^{\circ}, \mathrm{W} 4.9181^{\circ}$ \\
\hline CARL & 80.53 & 80.06 & Carew River Lower & $\mathrm{N} 51.7123^{\circ}, \mathrm{W} 4.859^{\circ}$ \\
\hline CRRU & 65.70 & 80.61 & Cresswell River Upper & $\mathrm{N} 51.723^{\circ}, \mathrm{W} 4.8332^{\circ}$ \\
\hline CRRL & 37.69 & 68.38 & Cresswell River Lower & $\mathrm{N} 51.7213^{\circ}, \mathrm{W} 4.8757^{\circ}$ \\
\hline WCL & 55.38 & 74.65 & Western Cleddau Lower & $\mathrm{N} 51.7713^{\circ}, \mathrm{W} 4.9243^{\circ}$ \\
\hline WCU & 93.39 & 85.72 & Western Cleddau Upper & $\mathrm{N} 51.7878^{\circ}, \mathrm{W} 4.9434^{\circ}$ \\
\hline ECL & 37.53 & 55.53 & Eastern Cleddau Lower & $\mathrm{N} 51.7725^{\circ}, \mathrm{W} 4.8788^{\circ}$ \\
\hline ECU & 56.76 & 78.73 & Eastern Cleddau Upper & $\mathrm{N} 51.7901^{\circ}, \mathrm{W} 4.8379^{\circ}$ \\
\hline MH4 & & $45.30^{1}$ & Off Mine Depot jetty & N 51 $42.020^{\prime}$, W $5^{\circ} 00.8215^{\prime}$ \\
\hline MH10 & & $92.10^{1}$ & Off Llanreath & N $51^{\circ} 41.754^{\prime}, \mathrm{W} 4^{\circ} 58.2155^{\prime}$ \\
\hline VC23 & & $98.10^{2}$ & Pennar Gut & OS Easting 193872.1, Northing 202638.7 \\
\hline $\mathrm{VC} 24 \mathrm{a} / 1$ & & $95.80^{2}$ & Pennar Gut & OS Easting 194101.3, Northing 202674.6 \\
\hline
\end{tabular}


Laboratory chemistry analysis

The hydrocarbons methods used in 2010 are detailed by Fugro ERT (2012) and Little et al. (2015). All methods used in 2007, 2010 and 2012 involved gas chromatography analysis with flame ionization detection (GC-FID) of saturated hydrocarbons and gas chromatography-mass spectrometry (GC-MS) of PAHs. Following are summaries of NLS' methods for 2007 and 2012. With the exception of organotin and organic carbon analyses, NLS' methods were subject to inter-laboratory performance testing by 'Quasimeme', and with the additional exception of the PAH alkyl homologues, the methods were accredited by UK Accreditation Service. Method reporting verification (MRVs) levels were typically 2-5 $\mu \mathrm{g} / \mathrm{kg}$ (PAHs), $0.1 \mu \mathrm{g} / \mathrm{kg}$ (polychlorinated biphenyls, $\mathrm{PCBs}$ ), $0.02 \mathrm{mg} / \mathrm{kg}(\mathrm{Cd}), 0.002 \mathrm{mg} / \mathrm{kg}(\mathrm{Hg}), 0.07 \mathrm{mg} / \mathrm{kg}(\mathrm{Cr}), 1 \mathrm{mg} / \mathrm{kg}(\mathrm{Cu}), 0.2 \mathrm{mg} / \mathrm{kg}(\mathrm{Pb})$ and $3 \mu \mathrm{g} / \mathrm{kg}(\mathrm{Zn})$.

Certified reference material (CRM) was used as follows: USA National Institute of Standards and Technology 1941b (parent PAHs and PCBs), and Canadian National Research Council MESS-3 (metals). Precision was better than $15 \%$ for PAHs and $10 \%$ for metals. With the exception of organotin, PAHs and PCBs analyses, sediment was air-dried at $30^{\circ} \mathrm{C}$, crushed and screened at $2 \mathrm{~mm}$, and stored at $4^{\circ} \mathrm{C}$. The organotin samples were freeze-dried and stored at $-18^{\circ} \mathrm{C}$ in 2007 and analysed as received in 2012 . Samples for PAHs and PCBs analyses were stored at $-20^{\circ} \mathrm{C}$ and, after thawing, any large sediment particles were removed manually.

\section{Total Organic Carbon (TOC)}

Sediments were pre-treated to remove inorganic carbonates, separated by chromatography column using a CHN analyser, and quantified using a thermal conductivity detector.

\section{Tributyl Tin $(T B T)$}

Organotins were alkylated directly using sodium tetraethyl borate. The derivatised organotins were then extracted into iso-octane and some was pipetted off into an auto-sampler vial. The resulting extracts were then analysed using GC-MS with selected ion monitoring (SIM) detection. In 2012, the extraction was by acetic $\mathrm{acid} / \mathrm{methanol.}$

\section{Metals}

The dried sample ( $<2 \mathrm{~mm}$ fraction) was digested in a mixture of nitric and hydrochloric acids ('aqua regia') using a microwave. The digest was evaporated to dryness and re-dissolved in hydrochloric acid ( $\mathrm{HCl})$. For all except $\mathrm{Hg}$, the metals were determined using inductively coupled plasma-mass spectrometry (ICP-MS). For $\mathrm{Hg}$, the analysis was by cold vapour atomic fluorescence spectroscopy.

PAHs

The sediment sample was initially extracted using an accelerated solvent extraction (ASE) system using 50/50 dichloromethane/acetone. The extract was cleaned up using gel permeation chromatography (GPC) and silica gel, and analysed using GC-MS in SIM mode. A total of 20 parent PAHs was analysed in both years, nine alkylated PAHs in 2007, and up to 20 alkylated PAHs in 2012.

$P C B s$

Surrogate standards were added to the sample which was extracted using a solvent mix of dichloromethane/acetone under ASE conditions, and reduced in volume. By use of high resolution size exclusion chromatography (SEC)/GPC, any interfering organic compounds of high molecular weight, elemental sulphur and mineral oils were removed. To isolate seven PCBs recommended by the International Council for Exploration of the Sea $\left(\mathrm{PCB} \mathrm{ICES}_{7}\right)$, the fractionated extract was further cleaned up on florisil and silica columns, and concentrated to low volume prior to analysis using GC-MS in SIM mode.

Data analysis

The variance and means of the sediment contaminants were compared using the F- and t-tests, and $95 \%$ confidence limits were calculated on mean values. Sediment contaminants data for 2007-2012 were then screened against international sediment quality guidelines (SQGs) to assess and help manage MHW contaminants. The SQGs developed by Environment Canada (EC) and the US National Oceanic and 
Atmospheric Administration (NOAA) were used. The Threshold Effects Level (TEL) and Probable Effects Level (PEL) allow managers to predict biological impacts in benthic communities from sediment contaminant concentrations. TELs are based on field data showing initiation of biological impacts in sediments in from $13 \%$ to $37 \%$ of the case studies examined by EC. PELs are based on effects found in from $37 \%$ to $83 \%$ of such studies (www.ec.gc.ca). The Oslo and Paris Commissions (OSPAR 2009a-c) adapted the similar NOAA approach of Effects Ranges Low and Medium (www.ospar.org/). Note also that instead of 'aqua regia' extracts as used in this study, SQGs typically use data from total digests involving hydrofluoric acid, which would have increased the extent of metals exceedance reported here.

For the independent biological monitoring data, the chi-square test was used to evaluate how likely it was that an observed departure from homogeneity of the frequency distributions of abundance through time arose by chance across each of the datasets.

Independent monitoring and other surveys

Sediment PAHs data are generated periodically by CEFAS for sediments sampled within MHW berthing boxes and channels as part of the licensing process for dredging. Contaminants are also measured annually as part of the Clean Safe Seas Environmental Monitoring Programme (CSEMP, 2014). For this, NLS data for PAHs in sediments at Cosheston Point two km upstream of Neyland (Fig. 1) were accessed from the Marine Environment Monitoring and Assessment National (MERMAN) database.

To assess whether MHW catchment influx was commensurate with temporal change in contaminants, data from three radionuclide-dated sediment cores from July 1986 in MHW were used. To assess sediment transport markers, using silt-grade fluorescent tracers released daily during disposal offshore Neyland on spring and neap tides in September - October 2001, ETS (2002) sampled sediments for tracers in 128 settled fine sediment locations during one month. Using Acoustic Doppler Current Profiling (ADCP), Longdin and Browning (2002) followed plumes arising from dredging works in April 2002 at Petroplus and in May 2002 at Texaco (now Valero) during spring and neap tides.

Visual evidence for sediment disturbance was gathered from MHWESG's survey of subtidal sedimentary habitats using sediment profile imagery (SPI) and plan views (PV) at 550 stations in MHW. This was conducted in May 2012 by Germano \& Associates, Inc. (2013). SPI/PV images were then assigned to sedimentary facies and to the benthic classification of the European Nature Information System (EUNIS; www.eunis.eea.europa.eu/habitats/; Carey et al. 2014). The SPI/PV system provides information on bedform and surficial stratigraphy, the degree of wave or current influence, while the influence of storms or sediment plumes can be inferred. SPI/PV also provides data on structurally dominant biota. Carey et al. (2014) demonstrated that most MHW facies have counterparts in the EUNIS classification. Importantly, the facies without EUNIS counterparts are those defined by stratigraphy: e.g. muddy fine sand with a surface armour of pebbles and shells (H1 facies), which indicates winnowing of mixed gravel/sand/mud sediments; or sand-overmud (H2 facies), which indicates episodic sediment transport. Both these cases show the effect of sedimentary processes on benthic habitats, and the value of facies in habitat mapping. Using the facies approach, an attempt was made to evaluate stability or change in order to discriminate natural and anthropogenic impacts.

Dredging data were collected from records held for 1985-2012 by MHPA (2011) and pers. comm. MHPA (2012) and further interpretation was provided by their consultant, M. Maloney (pers. comm. 2013). Marina disposals from NYH were derived from Cascade Consulting (2011) and Camplin (2008).

Waterbirds use intertidal sediment flats and wetlands to feed, rest, migrate and spend winter. Therefore, bird numbers may reflect changes in environmental quality in these habitats, as well as on flyways and in breeding grounds in higher latitudes. Non-breeding waterbirds in the UK are monitored by coordinated counters in the national Wetland Bird Survey (WeBS). For many species, WeBS counts are sufficient to smooth inter-annual variation and track long-term trends. When possible, site-specific factors in MHW were separated from widerscale factors such as changes in migration patterns due to recent milder winters and longer-term climate change.

A range of other vertebrate and invertebrate biota was monitored in MHW each year during the decade 2002 to 2012 by the Field Studies Council (FSC), NRW and the Wildlife Trust of South and West Wales (WTSWW). In all cases the populations had recovered from any immediate post-'Sea Empress' effects prior to, or early during, the monitoring period. The species were two starfish Asterina gibbosa and A. phylactica at West Angle Bay (Crump 2013); limpet Patella vulgata at Dale (Archer-Thomson 2013); and live pup births of grey seal Halichoerus grypus counted just outside MHW on the Castlemartin Peninsula (pers. comm. A. Bunker), and in the nearby Skomer Marine Nature Reserve (Boyle 2012).

Bioaccumulation in MHW was surveyed for MHWESG by Langston et al. (2012a, b). Using a range of organisms including mussel Mytilus edulis (water and SPM filter-feeder), and ragworm Hediste diversicolor (omnivore sediment ingester), the uptake of bioavailable contaminants was monitored between late 2007/early 2008 and 2010 for $\Sigma \mathrm{PAH}_{17}, \mathrm{PCB} \mathrm{ICES}_{7}$, organotins and trace metals. The bioaccumulation sampling dates and some stations were very close to those used in the present work and by Little et al. (2015). 


\section{Results and discussion}

Total PAHs and other contaminants

MHW-wide surveys 2007 and 2012

Natural Resources Wales (NRW) provided survey data from 2007 and 2012 of PAHs in the surface sediments of all the main bays and sub-estuaries of MHW. The Fugro ERT data for 2010 and NLS PAHs and other contaminants data are given in Electronic Supplementary Material (ESM) Tables 1-4. The PAH data showed good agreement between the two laboratories, particularly for parent PAHs (Little et al. 2015). In order to establish the comparability of the NRW 2007 and 2012 data, the total PAHs ( $\mathrm{PPAH}$ ) trends were compared to those for other contaminants. Table 2 shows that in 2007 the concentrations of TOC, tributyltin, $\mathrm{Hg}, \mathrm{Cd}, \mathrm{Cr}$, $\mathrm{Cu}, \mathrm{Pb}, \mathrm{Zn}$ and PAHs were all positively correlated with sediment particles $<63 \mu \mathrm{m}$ diameter (\% mud). In 2012 , PCBs were also correlated with $\%$ mud at $p<0.01$, in addition to $\%$ TOC and the above contaminants. With the exception of TBT and $\mathrm{Hg}$, the metals were more correlated $(p<0.01)$ with \% TOC than with \% mud in 2007.

In 2012, with the exception of $\mathrm{Cd}$ and $\mathrm{Zn}$, the metals correlation coefficients were higher with $\%$ mud than with \% TOC. Concentrations of TBT were below limit of detection (>LOD) only for 2007, and very weakly correlated with $\%$ mud $(p<0.1)$. In both years, although concentrations of Hg correlated with \% TOC $(p<0.02)$, the correlation was higher with $\%$ mud $(p<0.01)$. Concentrations of total PCBs were above LOD only for 2012, and like $\mathrm{Hg}$, they were also correlated more strongly with $\%$ mud $(p<0.01)$ than with $\%$ TOC $(p<0.05)$.

In contrast to the metals, concentrations of total PAHs were correlated less with TOC in $2007(p<0.02)$ than in 2012 ( $p<0.01)$. There was less $\Sigma$ PAHs correlation with mud in both years, and no significant correlation between the two years $(p<0.1)$. Other contaminants except $\mathrm{Hg}$ showed good correlations between the years $(p<0.01)$. The correlations between years were also highly-significant for $\%$ mud and $\%$ TOC. This suggests no major change in these two master variables from 2007 to 2012, importantly for comparability (Table 2). The fact that the concentration ranges of all six heavy metals, TBT and EPAHs all decreased between 2007 and 2012 without commensurate changes in $\%$ mud and \% TOC suggests that field sampling, sediment patchiness or changes in the various laboratory methods used by NLS cannot alone explain the results.

The sediment homogeneity in 2012 is further illustrated by the five grain size replicates at each station for which the average coefficient of variation (CV) was 17.6\%. If the Sandyhaven (SHU and SHL) samples are excluded, being coarse sediment (and with the lowest contaminant loadings), the average CV was only $11.2 \%$. If the sediment itself had decreased in $\%$ mud or $\%$ TOC, then this might account for the decreases in metals and PAHs. In fact, there were slight increases in these master variables between 2007 and $2012(11 \%$ increase in $\%$ mud and 24\% increase in \% TOC). However, when variances were tested using the F-test and means were then tested using the t-distribution, these increases in \% mud and \% TOC were non-significant. Given the highly significant correlations of almost every contaminant with \% mud and \% TOC, and in line with their stability, the expectation would be for stable contaminants and not for the decreases observed between 2007 and 2012.

Table 2 Spearman Rank Correlation coefficients $\left(\mathrm{r}_{\mathrm{s}}\right)$ in MHW for 2007 and 2012 between sediment mud content, organic carbon (TOC), tributyltin (TBT), mercury (Hg), cadmium (Cd), chromium $(\mathrm{Cr})$, copper $(\mathrm{Cu})$, lead $(\mathrm{Pb})$, zinc $(\mathrm{Zn})$, sum of 29 PAHs $\left(\Sigma \mathrm{PAH}_{29}\right)$, and $\Sigma \mathrm{PCB} \mathrm{ICES}_{7}$. Also shown are $\mathrm{r}_{\mathrm{s}}$ between the 2007 and 2012 ranks

\begin{tabular}{llllllllllll}
\hline & Mud & TOC & TBT & Hg & Cd & Cr & Cu & Pb & Zn & $\Sigma \mathbf{P A H}_{29}$ & $\Sigma \mathbf{P C B}_{7}$ \\
\hline $2007 \mathrm{v}$. & 1.0 & -- & -- & 0.77 & 0.56 & 0.60 & 0.66 & 0.81 & 0.69 & 0.54 & -- \\
mud & & & & $* * *$ & $*$ & $*$ & $* *$ & $* * *$ & $* * *$ & $*$ & \\
$2007 \mathrm{v}$. & & 1.0 & -- & 0.63 & 0.80 & 0.82 & 0.83 & 0.83 & 0.79 & 0.63 & -- \\
TOC & & & & $* *$ & $* * *$ & $* * *$ & $* * *$ & $* * *$ & $* * *$ & $* *$ & \\
$2012 \mathrm{v}$. & 1.0 & 0.80 & -- & 0.74 & 0.59 & 0.86 & 0.81 & 0.87 & 0.74 & 0.54 & 0.77 \\
mud & & $* * *$ & & $* * *$ & $*$ & $* * *$ & $* * *$ & $* * *$ & $* *$ & $*$ & $* * *$ \\
2012 v. & & 1.0 & -- & 0.66 & 0.75 & 0.77 & 0.81 & 0.79 & 0.76 & 0.70 & 0.59 \\
TOC & & & & $* *$ & $* * *$ & $* * *$ & $* * *$ & $* * *$ & $* * *$ & $* * *$ & $*$ \\
2007 v. & 0.91 & 0.70 & -- & 0.55 & 0.91 & 0.81 & 0.93 & 0.83 & 0.86 & -- & -- \\
2012 & $* * *$ & $* * *$ & & $*$ & $* * *$ & $* * *$ & $* * *$ & $* * *$ & $* * *$ & & \\
\hline
\end{tabular}

[Source: NRW 2007 and 2012 Habitats Directive (1992) monitoring in MHW ( $\mathrm{n}=15$, two-tailed tests). Note: $\mathrm{r}_{\mathrm{s}} 1.0=$ perfect correlation, $\mathrm{r}_{\mathrm{s}}$ $* * *=$ significant at $p<0.01, \mathrm{r}_{\mathrm{s}} * *=$ significant at $p<0.02, \mathrm{r}_{\mathrm{s}} *=$ significant at $p<0.05, \mathrm{r}_{\mathrm{s}}--=$ no correlation, or weak correlation $(p<0.1)$, or data <limit of detection (LOD)]

The results showed that the metals data (except TBT, $\mathrm{Hg}$ and $\mathrm{Cd}$ for which decreases were not significant) significantly decreased in mean values between 2007 and 2012 (Table 3). For $\mathrm{Cr}$ and $\mathrm{Cu}$ these decreases were significant at $p<0.01$, and for $\mathrm{Pb}$ and $\mathrm{Zn}$ at $p<0.02(\mathrm{n}=15)$. The mean $\Sigma \mathrm{PAH}_{29}$ decreased from 10.67 to 3.85 $\mathrm{mg} / \mathrm{kg}$ between 2007 and $2012(p<0.01, \mathrm{n}=15)$. 
Table 3 Mean mud and TOC (\%), metals and $\Sigma \mathrm{PAH}_{29}(\mathrm{mg} / \mathrm{kg})$, TBT and $\Sigma \mathrm{PCB} \mathrm{ICES}_{7}(\mu \mathrm{g} / \mathrm{kg})$ in $\mathrm{MHW}$ for 2007- 2012

\begin{tabular}{llllllllllll}
\hline & Mud & TOC & TBT & Hg & Cd & Cr & Cu & Pb & Zn & $\Sigma \mathbf{P A H}_{29}$ & $\Sigma \mathbf{P C B}_{7}$ \\
\hline 2007 & 54.2 & 1.236 & -- & 0.12 & 0.242 & 42.65 & 25.26 & 33.84 & 126.6 & 10.67 & -- \\
& -- & -- & & -- & -- & $* * *$ & $* * *$ & $* *$ & $* *$ & $* * *$ & \\
2012 & 60.41 & 1.542 & -- & 0.095 & 0.197 & 28.85 & 17.26 & 30.18 & 120.0 & 3.85 & --
\end{tabular}

[Source: NRW 2007 and 2012 fine-grained surface sediments monitoring data in MHW bays and estuaries (Habitats Directive, 1992). Note: t-test results $* * *=$ changes significant at $p<0.01, * *=$ significant at $p<0.02,--=$ not significant in t-test, or insufficient data for TBT and $\Sigma \mathrm{PCB}_{7}$ due respectively to method change and many data points $\left.<\mathrm{LOD}\right]$

However, in contrast to the PAH and metals, the sum of PCBs increased in range from <LOD at almost every station to $2.77 \mu \mathrm{g} / \mathrm{kg}$ (at CPU) in 2007, to a range from <LOD to $3.64 \mu \mathrm{g} / \mathrm{kg}$ (at AH) in 2012, perhaps explained by the slightly increased \% mud and \% TOC levels. Unlike PCBs, the PAHs and four metals all significantly decreased between 2007 and 2012, when the \% mud and \% TOC would predict stable levels.

The changes through time since the first MHW-wide survey of PAHs (1993) are shown in Fig. 2. Data are broadly comparable, being analysed by NLS in all surveys except 2010, which was by Fugro ERT (2012). The range of PAH compounds was limited to $\mathrm{SPAH}_{18}$ to improve comparability with the earlier work. Numbers of comparable samples analysed were 33 in 1993, 35 in 1996, 15 in 2007, 12 in 2010, and 15 in 2012. Although variability was high due to poor sediment sorting in the two earlier surveys, the larger number of stations analysed shows that a clear increase in mean $\Sigma$ PAHs from $1996(2.99 \mathrm{mg} / \mathrm{kg})$ to $2007(8.13 \mathrm{mg} / \mathrm{kg})$ is significant at $p<0.01$.

In addition to the two year comparison in Table 3 above, the extra surveys available in the longer time series show that the decrease in PAH concentrations from $2007(8.13 \mathrm{mg} / \mathrm{kg})$ to $2010(4.58 \mathrm{mg} / \mathrm{kg})$ is also significant $(p<0.05)$. The time series shows that in late 2007 significantly higher total PAH mean concentrations occurred than either before $(p<0.01)$, or since $(p<0.05$; t-test). No other changes plotted in Fig. 2 were statistically significant. Instead, it appears that between 3 and $4.5 \mathrm{mg} / \mathrm{kg} \Sigma \mathrm{PAH}_{18}$ is a benchmark for total PAHs in sediments over a wide area of MHW during 20 years, including the period before and after 'Sea Empress'. Note that 2007 stands in stark contrast to that benchmark, and cannot be explained by changes in laboratory methods.

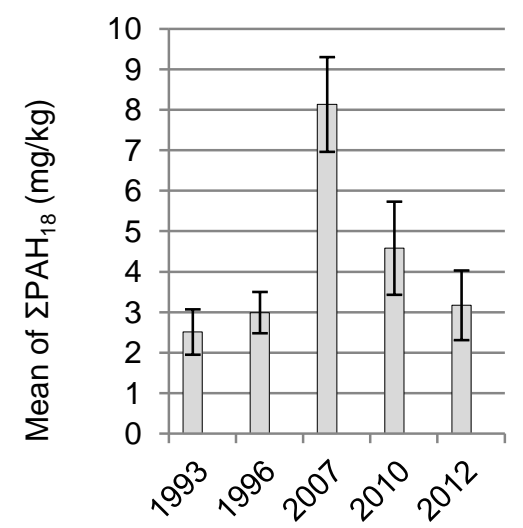

Fig. 2 Mean and $95 \%$ confidence limits (range in population mean) of $\Sigma \mathrm{PAH}_{18}$ concentrations (mg/kg) in $\mathrm{MHW}$-wide sediments 1993-2012, sampled October or November [Sources: Levell et al. (1997); Fugro ERT (2012); pers.comm. NRW]

There were initially dramatic drops in the mean $\Sigma$ PAHs from 2007-2010. Then, from 2010-2012 there was a further, non-significant decrease overall. PAHs concentrations in the lower to mid-MHW dropped steeply from 2010 to 2012 at the same time as the upstream stations increased by very similar amounts, as if a pulse of suspended particulate material (SPM) passed up-estuary during these two years. Sediment may have been flushed down-river from the MHW catchments into the upper tributaries, accounting for changes in PAHs and metals, although they would not be synchronised across all the tributaries without aerial input.

The changes in PAHs and metals concentrations from 2007 to 2012 are instead ascribed to the onset, cessation and relaxation of disturbance arising during construction of LNG-related facilities in MHW. This hypothesis whereby historic pyrogenic PAH and metals from subsurface sediments are resuspended could explain the PAHs and metals trends. The possible sources of disturbance are mainly from dredging operations peaking in 2006 and 2008-2011. The SPM then apparently settle on surface sediments, causing very high PAH levels by late 2007. Subsequently, the settled particles are partly buried by bioturbation or sedimentation, or moved by estuarine circulation, both of which would reduce sediment PAHs by dilution 2010-2012, except at 
sites near ongoing disturbance. Then, by 2012 with prolonged transport, there is sorting and focusing of contaminated sediment into the upper reaches of MHW's sub-estuaries.

The above hypothesis suggesting a pulse of remobilized PAHs from disturbed surficial sediments is explored station-by-station below (with cross-references to possible evidence for biological effects):

(1) Between 2007 and 2010 considering up to $\mathrm{\Sigma PAH}_{29}$ that were comparable for these two years, Pembroke River and Angle Bay stations PRU, PRL, AH and less so AB and CPU (see Fig. 1), were the only stations that showed relative stability or increase in concentrations of up to 13 individual PAHs. Decreases occurred in all PAH at all other stations. On flood and ebb tide respectively, Pembroke River and Angle Bay appear to be proximal sedimentation zones of effect arising from construction and dredging in mid-MHW from 2006-2011 (see 'Bioaccumulation surveillance').

(2) Between 2010 and 2012 if the increases and decreases are calculated for the comparable $\Sigma \mathrm{PAH}_{37}$, the results fall into very logical spatial groupings in MHW. Increases in PAH in the period 2007-2010 then apparently shifted up-estuary from 2010-2012, partly due to dredging operations being further up-estuary than in the earlier period, but also due to the dispersion of SPM into more distal zones (see 'Sediment quality guidelines'). The relative changes 2010-2012 are summarized below:

- Increase: PRU (6\%), CARL (128\%), CRRL (10\%), WCL (72\%), ECL (59\%) and ECU (29\%) average $51 \%$, all in the upper reaches of MHW; and

- Decrease: AH (-70\%), AB (-73\%), PRL (-71\%), CPU (-42\%), CPL (-67\%), CRRU (-17\%) average -57\%, all but the last are stations in lower-middle MHW.

\section{Dredging licensing}

The PAHs data are presented in Fig. 3 for sediments sampled within MHW berthing boxes and channels as part of the licensing process for dredging. Berthing boxes generally showed PAHs concentrations between 3-4 $\mathrm{mg} / \mathrm{kg} \Sigma \mathrm{PAH}_{22}$, with a tendency for concentrations to increase in 2009 and 2012 at Dragon LNG and SemLogistics. There were occasional higher concentrations (e.g. in 2006 at Petroplus), and lower concentrations (e.g. 2007 at SemLogistics 3), and this contrast suggests that berths dredged in 2006 may be sources for widearea secondary contamination in 2007. The PAH fingerprint of the sediments in 2007-2012 overlaps with the 2001-2006 dredging samples, which reinforces that hypothesis (Little et al. 2015). In addition to their use for licensing, the pre-dredging PAHs and metals concentrations in berthing boxes represent a useful monitoring indicator. ESM-Table 5 shows decreasing metals concentrations between 1983-1992 and 1993-2006 that would support their use in this role (Little 2009).

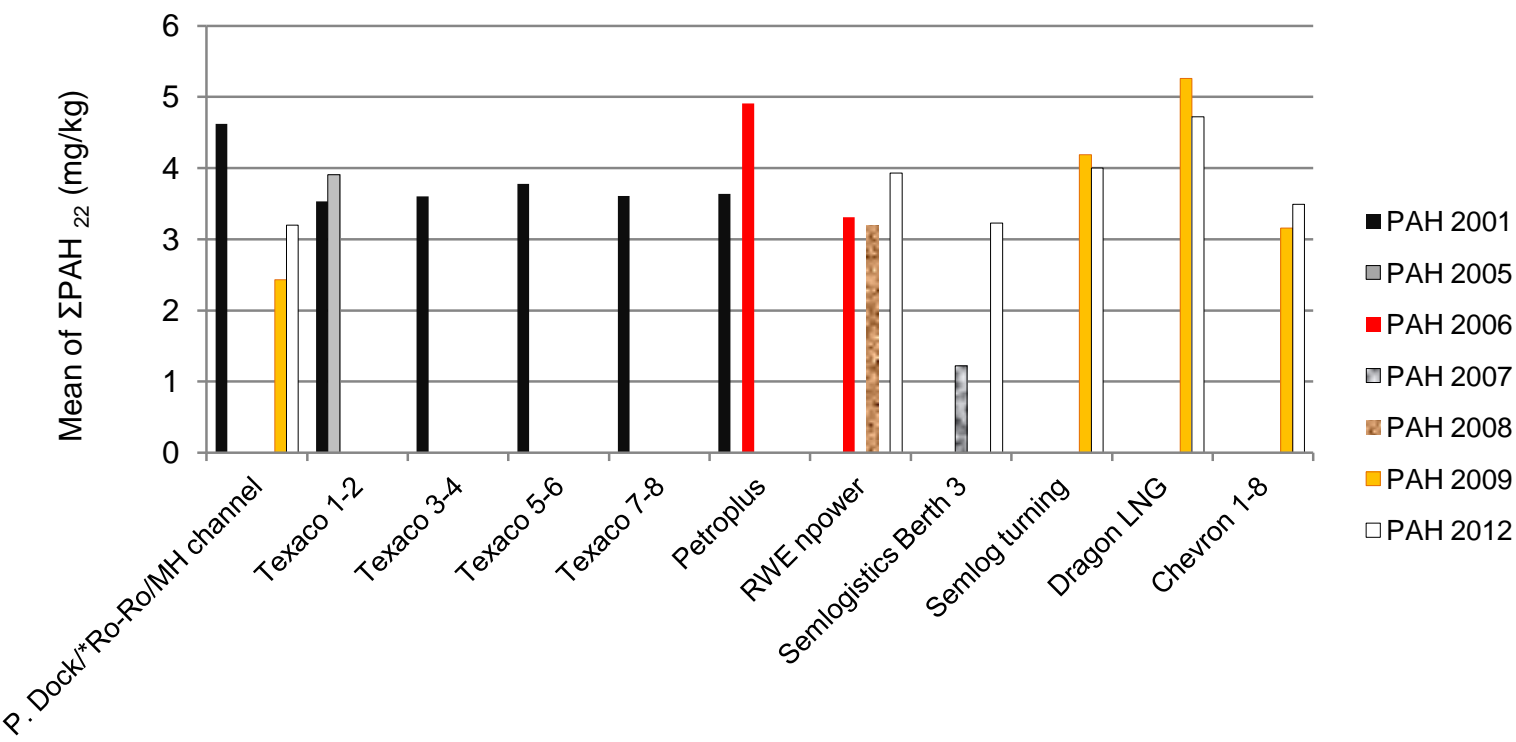

Fig. 3 Mean $\Sigma \mathrm{PAH}_{22}$ concentrations (mg/kg) in MHW dredged berthing boxes and channels, 2001-2012, *N.B. excluding one sample at Site 'T' Ro-Ro berth in Pembroke Dock on 31 March 2012 that was $\Sigma \mathrm{PAH}_{22}=118.44 \mathrm{mg} / \mathrm{kg}$. Note: Texaco, Chevron and Valero are the same marine terminal site, as are Petroplus, SemLogistics (= Semlog) and Dragon LNG (see Fig. 1 for site locations) [Source: pers. comm. CEFAS]

\section{Cosheston Point CSEMP station}

Fig. 4a shows that a pronounced double peak in $\Sigma \mathrm{PAH}_{10}$ and fluoranthene concentrations occurred at Cosheston Point in both 2008 and 2011 (CSEMP 2014). Copper concentrations and Cu/Al ratios reflect this PAHs signal, 
except with an earlier $\mathrm{Cu}$ peak in 2003, and in contrast to the March 2008 peak in PAHs the peak in $\mathrm{Cu}$ was March 2007 (Fig. 4b). In addition, there was a reported peak in $\mathrm{Cu}$ effluent discharges from Valero in 2007.
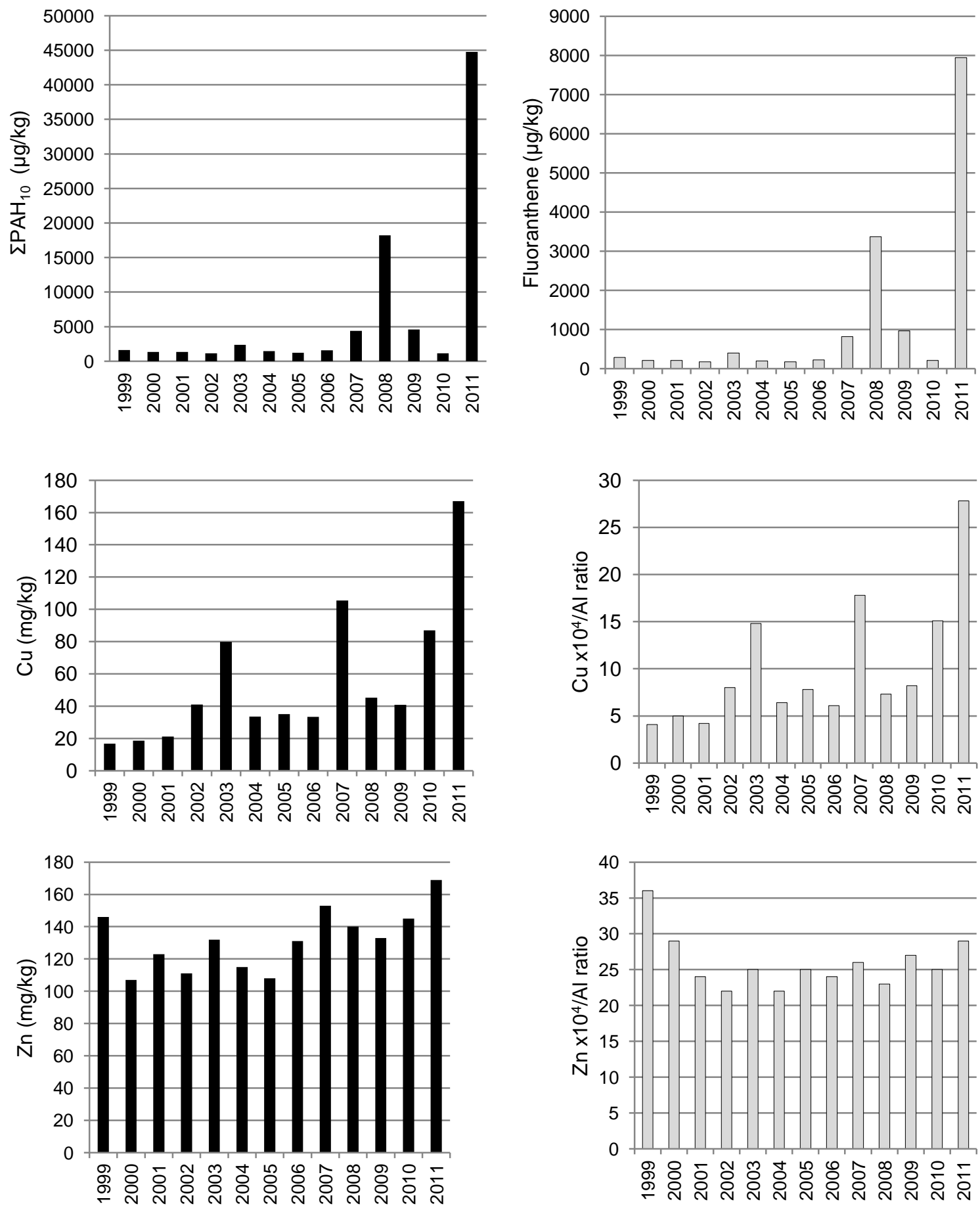

Fig. 4 Cosheston Point CSEMP site annual variation 1999-2011 in sediment means of five replicates: (a) at top, $\Sigma \mathrm{PAH}_{10}$ (left) and fluoranthene (right) $\mu \mathrm{g} / \mathrm{kg}$; (b) at middle, $\mathrm{Cu} \mathrm{mg} / \mathrm{kg}$ (left) and $\mathrm{Cu} / \mathrm{Al}$ ratios (right); (c) at bottom, $\mathrm{Zn} \mathrm{mg} / \mathrm{kg}$ (left) and $\mathrm{Zn} / \mathrm{Al}$ ratios (right); note differing y axis scales [Source: CSEMP 2014 (via MERMAN)]

Average PAHs concentrations $\left(\mathrm{PAH}_{10}\right)$ at Cosheston Point were more than an order of magnitude higher after $2006(14.6 \mathrm{mg} / \mathrm{kg})$ than before $(1.3 \mathrm{mg} / \mathrm{kg})$. Copper concentrations also increased, but only by a factor of 2.5 (Figs. 4a and b). Little et al. (1987) demonstrated that THC and $\mathrm{Cu}$ concentrations, fate and behaviour in MHW were coupled, and originated both naturally and from refinery effluents and sewage inputs to the system. The two sets of peaks were contemporaneous with inputs from dredging sources, and they contradict neither the STA findings nor the 2007 and $2012 \mathrm{MHW}$-wide data. 
Data for Zn concentrations at Cosheston Point show that peaks occurred in 1999, as well as 2003, 2007 and 2011 (Fig. 4c). However, when the raw $\mathrm{Zn}$ concentrations were normalized to sediment $\mathrm{Al}$ content, all but the 1999-2000 peaks were muted, and the pattern became more biennial, perhaps indicating $\mathrm{Zn}$ corrosion in effluents. This contrasted with the $\mathrm{Cu} / \mathrm{Al}$ ratios where normalization showed the same pattern as the raw $\mathrm{Cu}$ data, suggesting that sediment transport of Al-rich silts and clays was a dominant factor (Fig. 4b).

The CSEMP time series shows that the increase started at Cosheston Point in 2003 with a doubling of $\mathrm{Cu}$ and PAHs concentrations. Further large increases of PAHs and $\mathrm{Cu}$ concentrations occurred between 2003 and 2007/8, and again between 2007/8 and 2011. However, the latter result for Cosheston Point was in contrast to the MHW-wide survey between 2007 and 2010, when PAHs concentrations fell by 44\% ( $p<0.05)$. This decrease was more than could be explained by using a drop of $8.2 \%$ in road fuels sales as proxy for a reduction in inputs from atmosphere and road runoff (DECC 2013). Cosheston Point sediment was clearly subject to ongoing inputs of SPM through this narrow reach located immediately upstream of the industrialised sections of MHW.

\section{Sediment transport markers}

Although representing an integration of all the transport processes and directions working on the sediment grain size distributions and sorting gradients in MHW, the STA did not assess timescales (McLaren and Little 1987). The sediment transport rates for the surficial $(<2 \mathrm{~cm})$ sediments implied by the contaminant trends in MHW are rather slow, integrating ebb and flood transport in the range of several months to one year over the $\sim 30 \mathrm{~km}$ axial length of MHW.

To assess whether catchment influx is commensurate with temporal change and transport of sediment contaminants, results from three sources were as follows: (1) three radionuclide-dated sediment cores from July 1986 in MHW showed no evidence of 'new' Chernobyl ${ }^{137} \mathrm{Cs}$ fallout in the catchment and flushing into MHW within two months of the 26 April 1986 reactor explosion (Little 2009); (2) silt-grade fluorescent tracers were found in high concentrations (>100,001 particle counts/ml) from dredging plumes reached Garron Pill 5 km upestuary on spring flood tides and Llanstadwell $1.5 \mathrm{~km}$ down-estuary on the ebb. These represent sediment transport rates of 110-455 m/day (flood tide) and 150-335 m/day (ebb). Medium tracer concentrations (10,001100,000 counts/ml) reached Llangwm Pill $7 \mathrm{~km}$ up-estuary, and Wear Point, Pwllcrochan and Pennar Gut (3-4 $\mathrm{km}$ ) down-estuary, representing transport rates of 280-2,300 m/day (flood) and on the ebb 120-500 m/day (ETS 2002); (3) using Acoustic Doppler Current Profiling (ADCP), plumes arising from dredging works showed that neap tide sediment plumes travelled between $500 \mathrm{~m}$ (ebb tide) and $1,750 \mathrm{~m}$ (flood tide) upriver to where interaction with plumes at Petroplus occurred. Unfortunately, there were problems with spring tide measurements at Petroplus, and the only detectable plume travelled (flood) between 500-750 m (Longdin and Browning 2002).

Hebog (2006) summarised the same plume data as Longdin and Browning (2002), comparing them to the baseline, to the benthos and chemistry data in the dredged areas, and at increasing distances from them. From this, an estimate of $400 \mathrm{~m}$ transport radius of the plume was adopted in the RWE npower Environmental Statement (2007) to predict 55 ha of sediment deposition of $4.3 \mathrm{~mm}$ thickness in Pembroke River arising from dredging the water intake, and 42 ha at $1.2 \mathrm{~mm}$ arising from the Pwllcrochan Flats outfall channel works. In combination with other construction works, impact areas and duration would be greater.

\section{Visual evidence of physical processes}

Natural and anthropogenic impacts were distinguished using the facies approach which generally showed stable sediment types in 2012 when compared with sediment maps from grab and core sampling in 1982-84 (Carey et al. 2014; Rostron et al. 1986). However, the equivalent core photographs taken in 1982 for the three stations that corresponded in 2012 to the sand-over-mud (H2) facies indicate that no clear sand-over-mud layers were visible 30 years previously between Dale Roads and Milford Shelf (Little 2009). Therefore, over the last 30 years some sand-over-mud stratification has appeared. Work on the Gann Flats by Edwards et al. (1992) and author observations at Angle Bay show that fine sediments are winnowed from these intertidal flats, partly triggered by bait-digging activities. In the case of the Gann Flats, outwash from a former sand and gravel works at Mullock Bridge could also have helped develop the $\mathrm{H} 2$ facies in the subtidal in Dale Roads. The exposed beach at the mouth of Sandyhaven Pill experiences about $1 \mathrm{~m}$ height change seasonally and may contribute some ephemeral sand to the subtidal H2 facies nearby. Germano \& Associates, Inc. (2013) found visual evidence of disturbance at about 30 stations, and likely dredging material in seven stations in various facies, all but one (in Dale Roads) being near the marine terminals (Fig. 5). This suggests that LNG-related construction and dredging works in the middle reaches of MHW between 2003 and 2011 have left physical evidence of disturbance, including distinctive $\mathrm{H} 2$ sediment facies (Fig. 6). Facies $\mathrm{H}$ as a whole occupies 605 ha of the 3,750 ha seabed area of MHW surveyed in 2012 (pers. comm. M. Hayn). Less than 10\% of MHW is thus likely to be H2, although this facies represents only the portion of the study area that is visibly disturbed by dredging or construction. 


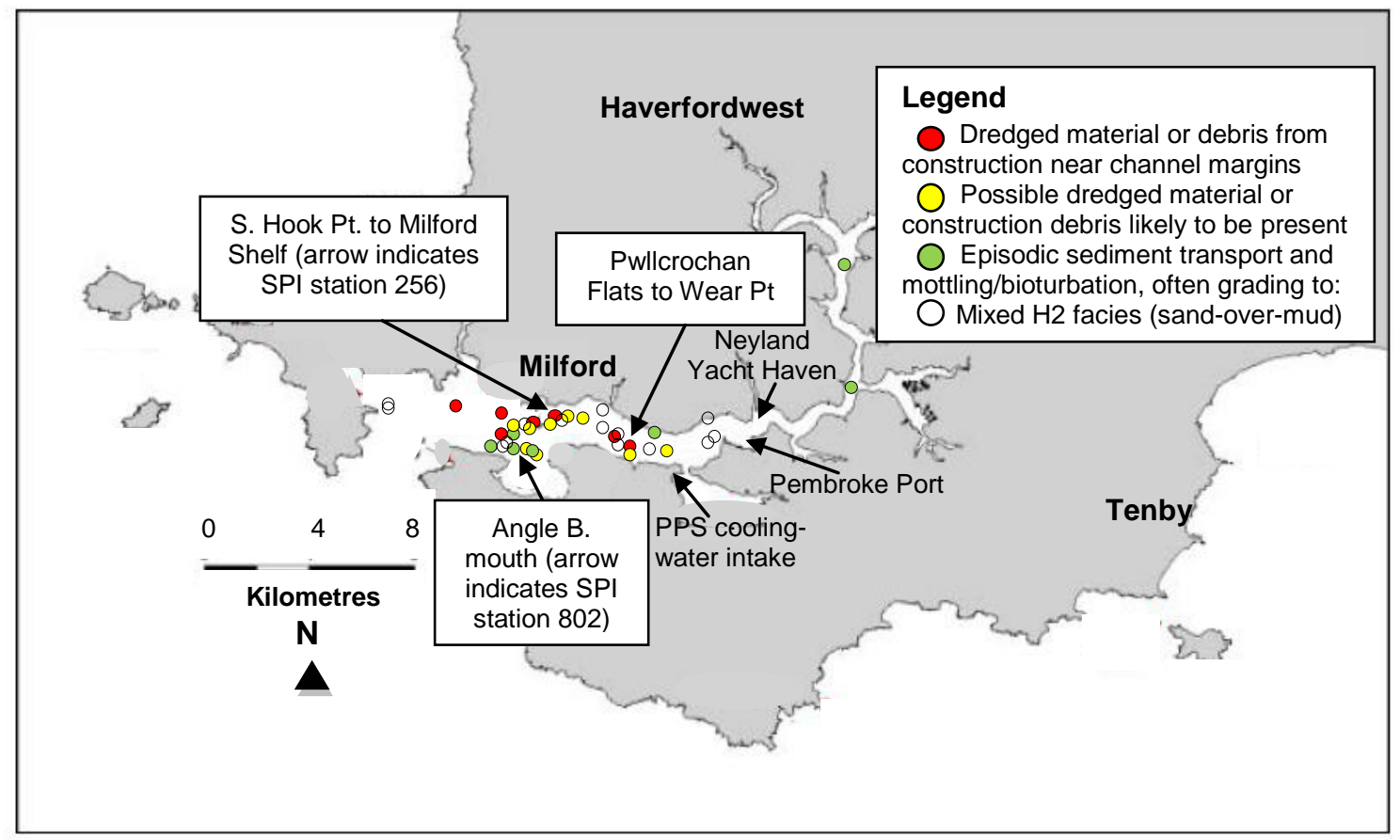

Fig. 5 Map showing three areas (boxed) of probable and possible dredging or construction disturbance, visible in May 2012 in SPI survey of MHW sediments; three other dredging areas also indicated, PPS = Pembroke Power Station [Source: Germano \& Associates, Inc. (2013); see Fig. 6]
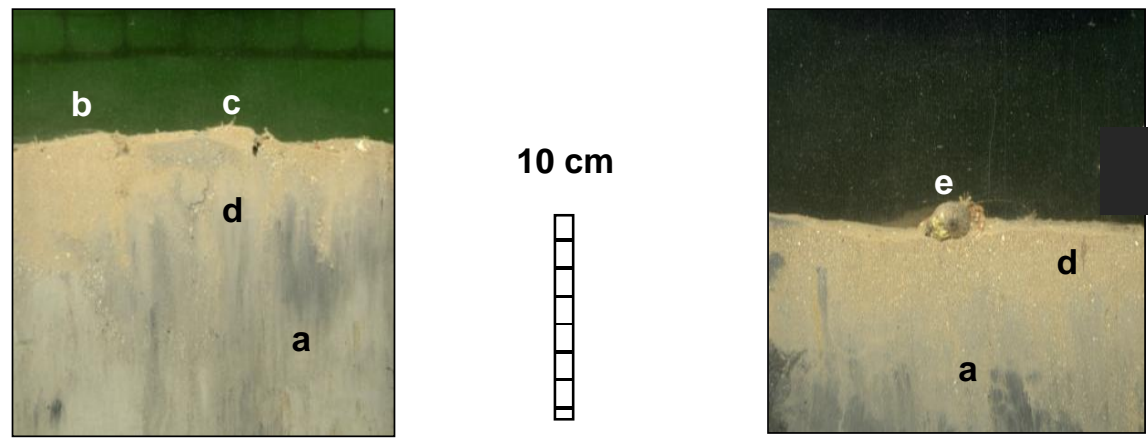

Fig. 6 SPI showing possible dredging effects in Facies H2 (sand-over-mud) with (a) chaotic bedding/ mottling, (b) current ripples/ episodic transport, (c) anemones, (d) burrowing polychaetes, (e) hermit crab [Source: Germano \& Associates, Inc. (2013). Note: at left is Station 256 offshore MHPA (N 51 $42.3757^{\prime} ;$ W 5 02.8980'; 22 May 2012) and at right is Station 802 off the mouth of Angle Bay (N 5141.5341'; W 504.1845'; 26 May 2012); see Fig. 5]

Although also occurring naturally in MHW (e.g. Dale Roads and Pennar Flats near Llanreath), the geometry of the $\mathrm{H} 2$ facies was elongated upstream on the northern shelf and downstream close to the southern shoreline, closely reflecting the original STA result (McLaren and Little 1987). In the relatively coarse-grained muddy sand sediments in the mid-reaches of MHW this is consistent with winnowing of mud from mixed sediments disturbed by dredging, due to their increased roughness, to leave a sandy surface layer.

For the finer-grained silts and clays, the spatial arrangement of mud facies also followed closely the STApredicted areas of deposition in the innermost reaches of MHW at the distal ends of flood-tide dominated pathways. This is due to deposition from SPM augmented by flocculation in the estuarine mixing zones, by sediment bio-packaging by animals, and by current-baffling and sediment trapping by saltmarsh plants. The muds resuspended from practically anywhere in MHW are thus concentrated along with their attached pollutant loading into the more quiescent innermost reaches and the uppermost flats and saltmarshes. Fine sediment behaviour influences the fate of contaminants not only in industrial reaches of MHW but also in rural tributaries such as Sandyhaven Pill, Eastern Cleddau, Carew and Cresswell Rivers.

Fine cohesive sediment particles require higher current velocities to be eroded than they did to be deposited; this is called the 'scour lag'. Fine sediment settles in places where particle settling velocities exceed the erosion velocity; this 'settling lag' displaces particles stepwise in the flood current direction (Van Straaten and Kuenen 
1958). In combination with velocity asymmetry between ebb and flood tides, the scour lag and settling lag produce net landward transport until the settling and erosion velocities reach equilibrium. The result is the shoreward-fining and upward-fining stratigraphy diagnostic of intertidal flat sediments, but absent in facies $\mathrm{H} 2$.

Also indicated in Fig. 5 are further areas of dredging that have not caused visual effects in the SPI, for example backhoe dredging at Pembroke Power Station (PPS) cooling water intake, and trailing suction hopper and plough dredging at Port of Pembroke. This may be due to finer-grained local sediment types with less visual contrast than is the case with the sands and mixed sediments. Additionally, at Neyland Yacht Haven (NYH) marina spoils are disposed directly into the water column on ebb tides in a nearby high-energy reach. The latter method makes less visual impact than in sandier sediments at the site itself, but may cause long-distance contaminated mud transport.

Maintenance dredging

The Port of Milford Haven (PoMH; formerly MHPA) periodically carries out maintenance dredging of the channels and marine terminal berthing boxes. The amounts dredged are comparatively low, and since 1992 all licensed spoil disposal is far outside MHW (MHPA 2011). PoMH records since 1985 show that over half of all dredging was between 2006 and 2011, and the dredged quantities in both 2006 and 2010 were twice those in any single year from 1985 to 2006 (Fig. 7). About 60\% of all dredging and construction since 1985 has taken place on flood-tide dominated STA transport paths. The resultant trapping of sediment within MHW was predicted by McLaren and Little (1987) to contribute to the need for repeated dredging.

Dredging operations peaked in 2006 (MHPA maintenance dredging) and 2007-2008 (NYH marina) and concentrations of PAH and other contaminants in MHW and tributaries were highly-enriched by that time. By 2010 further MHPA dredging took place, but this was mainly in the PPS cooling water intake inside Pennar Gut from which SPM would be transported mainly up-estuary in Pembroke River, and in the reinstated PPS outfall channel from which SPM would be transported mainly down-estuary from Pwllcrochan Flats and across the mouth of and into Angle Bay. This could explain why PAH concentrations decreased across most of MHW in 2010. Further dredging took place in 2011, but this was a continuation of PPS works (also in Mill Bay and Thorn Island, where the impacts are minimal due to the relatively coarse sediments involved). In 2012, dredging activities were once again focussed in areas of slack water or flood-domination (Valero Berths 1-3, 6-8) as well as ebb-domination (Valero $4 \& 5$ ), and this may account for the slight upturn in PAH concentrations in tributary estuaries. Overall, the PAHs concentration changes from 2007 to 2012 are as would be as predicted by STA after disturbance of sediments contaminated by historical PAHs (Little and Bullimore 2015).
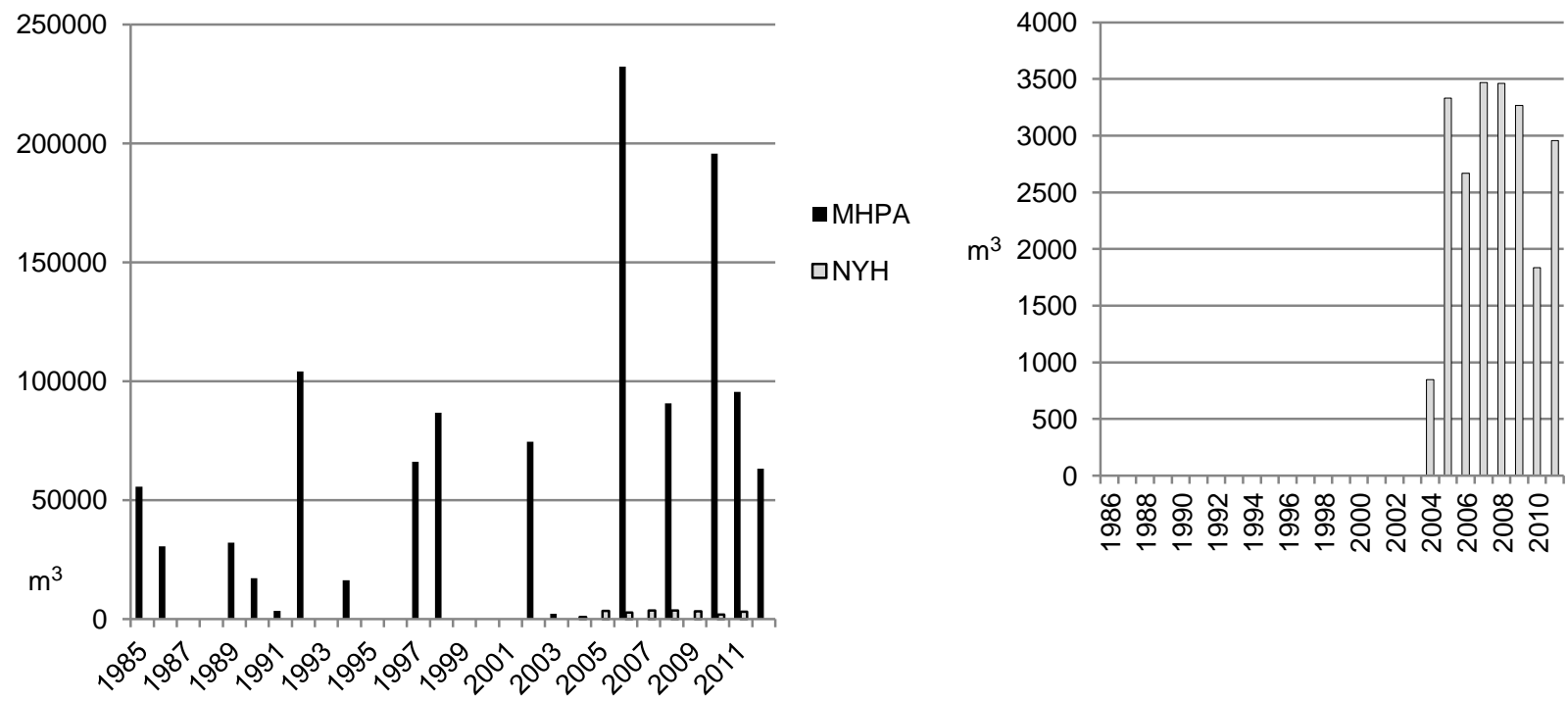

Fig. 7 Dredge spoil disposals ( $\mathrm{m}^{3}$ converted from tonnes using an assumed density of 1.5): (left) MHPA outside MHW, and NYH marina in ebb-tide main channel off Neyland; (right) x50 enlargement of NYH annual disposals [Sources: MHPA (2011) for ex-MHW disposals from 1985-2011, and pers. comm. MHPA for 2012; Cascade Consulting (2011) for NYH disposals from 2004-2011]

The sediment plume in Valero 4 \& 5 can be seen clearly in Fig. 8, with ebb flow indicated by arrows. There is virtually no flow during the flood tide and the extended slack water period permits SPM to accumulate on bed. PoMH's high-resolution bathymetry surveys showed that higher sedimentation rates are measured at 
Valero 4 \& 5 and in the sheltered mooring dolphin approaches to SemLogistics 2 \& 3 (pers. comm. M. Maloney). The intake channel for PPS in Pennar Gut (entrance to Pembroke River) is also an area of finegrained sedimentation. Pennar Gut and SemLogistics are flood-tide dominated, whereas Valero $4 \& 5$ is ebb-tide dominated. Sedimentation in the local sinks formed by these bathymetric lows agrees with the directions predicted by STA. Fig. 9 shows the sediment accretion in Valero 4 \& 5 between the post-dredging survey of October 2010 and the monitoring survey of September 2011. It is clear that the most rapid sedimentation takes place in the SE corner of the turning basin as a result of sediment transported from Pwllcrochan Flats by ebb tidal currents.

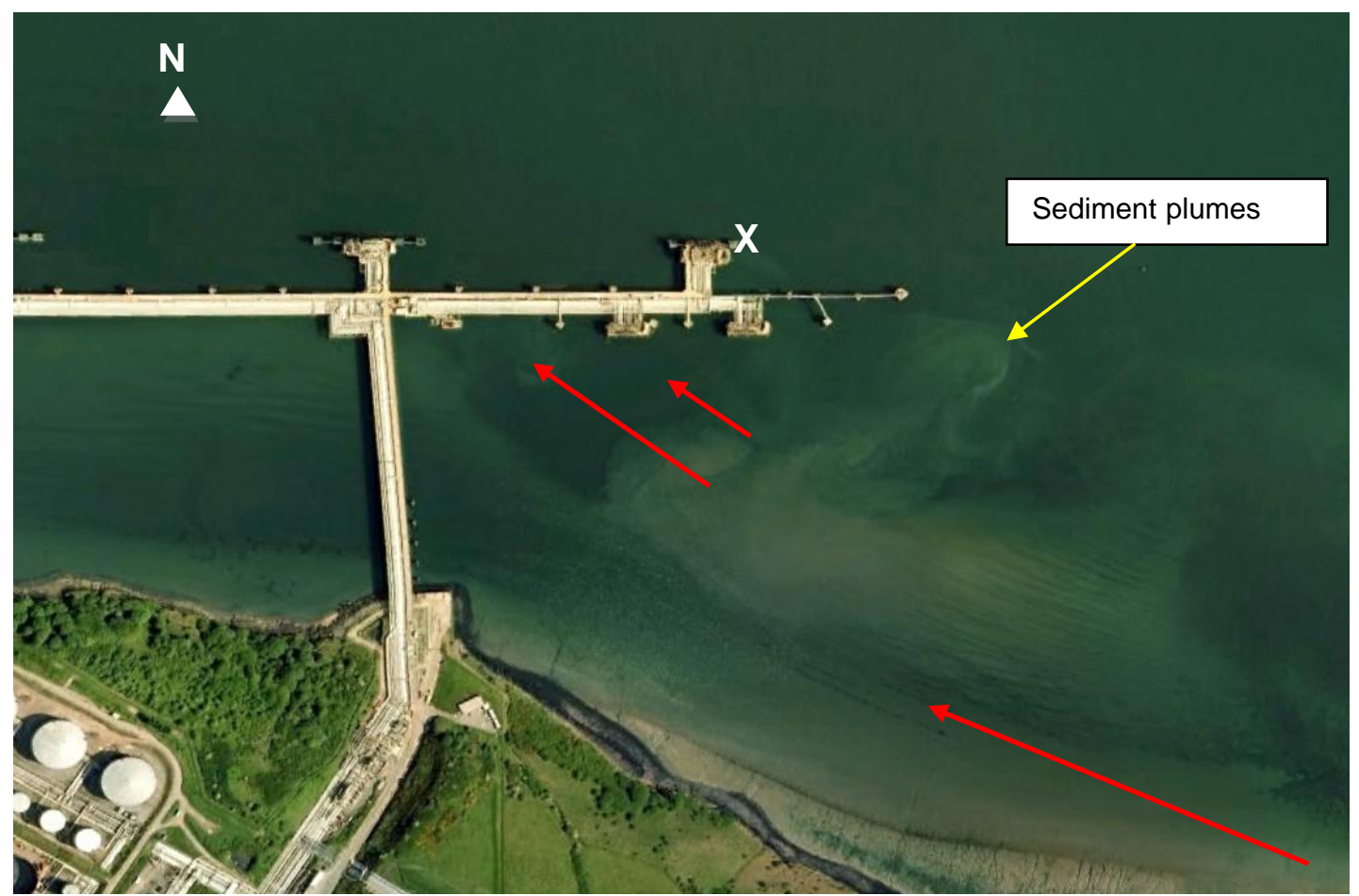

Fig. 8 Image showing mud furrow bed-forms oriented with ebb flow, and associated sediment plumes into Valero Berths 4 \& 5; location X also in Fig. 9 [Source: 'Google Earth', pers. comm. M. Maloney (2013)]

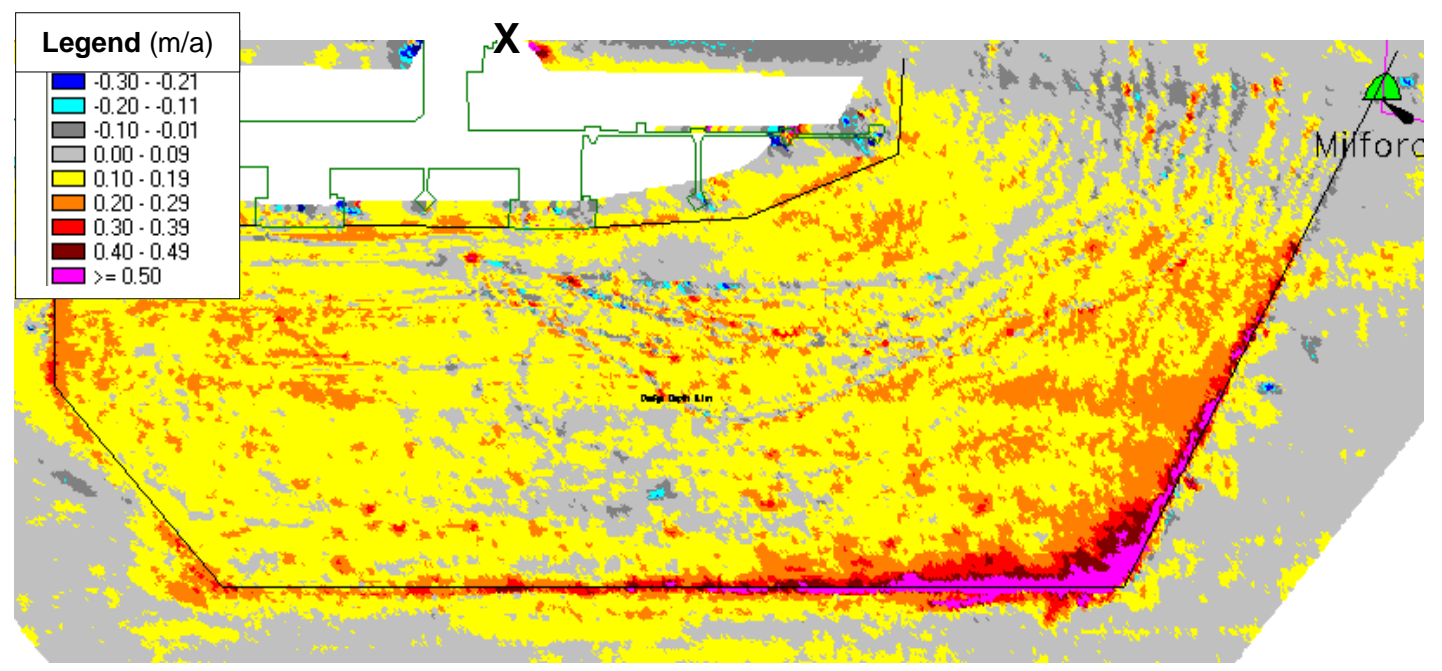

Fig. 9 Sedimentation rates (meters/annum) in Valero Berths 4 \& 5 between 2010 and 2011. Yellow, orange, red and magenta show accretion, greys show minor level changes between $+/-0.1 \mathrm{~m}$, and blues show erosion; location $\mathrm{X}$ also in Fig. 8 [Source: pers. comm. M. Maloney (2013)]

In the case of Pennar Gut, as part of the EIA by RWE npower (2007) several chemistry samples were reported prior to the dredging of the new PPS cooling water intake and outfall. In June 2006, the average $\Sigma \mathrm{PAH}_{22}$ concentration was $3.06 \mathrm{mg} / \mathrm{kg}$ at the intake area $(\mathrm{n}=6)$. By August 2010, $\Sigma \mathrm{PAH}_{19}$ averaged $1.77 \mathrm{mg} / \mathrm{kg}$ 
$(n=2$, this study) in surface layers of $3 \mathrm{~m}$ long vibracore samples taken by Jacobs in Pennar Gut. This indicates the effective reduction in the contaminated surface layer between 2006 and 2010, which would represent a potential source for contaminated sedimentation elsewhere. Dredging commenced in the PPS cooling water intake channel on 28 January 2010 with the required levels for the first phase being achieved on 11 April 2010. After the issuing of a revised disposal licence, dredging re-commenced on 9 October 2010 starting in the outfall site. This was completed on 21 October 2010. Dredging then re-started in the intake channel, and the required levels were achieved on 22 March 2011 (pers. comm. M. Maloney).

Trailing suction hopper dredging (TSHD) is the dominant method used for dredging in MHW, and according to Hebog (2006) can lose up to $38 \%$ of the silt/clay fraction as overflow from the hopper. The dredging strategy document (MHPA, 2011) emphasised that contracts now stipulate that hoppers are not permitted to overflow, yet the standard set (overflow density of $<1.07 \mathrm{t} / \mathrm{m}^{3}$ ) is sufficient to allow some of the finest sediments to escape. These will contain the highest concentrations of contaminants and will travel furthest from the area being dredged. Consequently, TSHD and other methods such as backhoes and ploughs will entrain fine sediment. Mitigation such as silt curtains are not feasible in MHW due to strong currents and wave action.

After disturbance by dredging and spillage, the contaminant concentrations could apparently increase due to sediment sorting during transport of only the finest material containing the highest loadings of contaminants, and eventual deposition in distal areas. It has been shown in numerous studies that hydrocarbon concentrations peak in the silt/clay fractions (including MHW, Little et al. 1987). Klamer et al. (1990) demonstrated the importance of grain size variations in assessment of PAHs and metals concentrations in sediments. Work on polluted urban soils shows that sorption strength of persistent organic pollutants peaks in silts (PAHs) and clays (PCBs), but that the very high TOC-water partition coefficients effectively sequester the pollutant reducing its bioavailability (Krauss and Wilcke 2002). Carls et al. (2008) suggested that greatest risk from PAH comes from slightly water-soluble dissolved PAH rather than from oil residues or droplets. From these studies, the higher surface area of silt/clay encourages PAH solution during resuspension, transport and pore-water squeezed during settling, leaving more weathered PAH by the time of final deposition.

To predict approximate amounts of PAH potentially involved in resuspension, and assuming between 3-5 $\mathrm{mg} / \mathrm{kg} \mathrm{\Sigma PAH}_{22}$ from berthing boxes from 2001-2006, then the maximum PAHs would be 600-1,000 kg in $200,000 \mathrm{t}$ of disposed dredge spoil (i.e. the peak spoils arising in 2006). Although the amount of PAH released from the spoils prior to leaving MHW is unknown, assuming that about 5,000 $\mathrm{t}$ spoil was lost from the 2006 peak of $200,000 \mathrm{t}$ (i.e. assuming $2.5 \%$ loss), this would equate to $15-25 \mathrm{~kg}$ PAHs. Recalling that up to $38 \%$ losses are reported in the literature, pessimistically this could amount to $>375 \mathrm{~kg}$ PAHs.

Warwick (2006, cited in MHPA, 2011) shows no significant differences in benthos between the 2002, 2003 and 2004 surveys conducted by Hebog (2006) pre- and post-dredging within the dredged berths at Valero and Petroplus. This was in spite of $c a .20 \%$ decreases in species diversity, abundance and biomass lasting more than 3 years. However, using multidimensional scaling (MDS) Warwick found differences between stations that had been dredged at any time in the past and those that had never been dredged. According to the dredging strategy document (MHPA 2011, page 33):

"the important point with respect to Pembrokeshire SAC is that the macrobenthos communities encountered within the area of long-term, albeit intermittent disturbance as a consequence of maintenance dredging are likely to be different from the non-disturbed communities, and are likely to have been so prior to the SAC designation in 1997".

This is logical, but does not give confidence that dredging impacts are reversible within $c a$. 3 years, as has been suggested in EIAs. Compliance of data with the pre- and post SAC designation in 1997 positively supports the dredging strategy. However, it would have been beneficial for the strategy to consider other monitoring results including the deficiencies in the Hebog surveys: real-time turbidity monitoring was difficult to accomplish; and nearly all PAHs results from their subcontracted laboratory were <LOD. In hindsight, it is thus questionable, at least for PAHs, whether these surveys had the power to resolve dredging impacts (Little 2009).

Warwick (2007) then investigated disturbance before and after capital dredging at Dragon LNG and South Hook LNG using abundance and biomass curves from two surveys conducted before dredging in January and March 2006 compared with a post-dredging survey in March 2007. Although there was very high variability, disturbance was found to be higher only in St. Bride's Bay (outside MHW). It is uncertain for LNG developments inside MHW whether these data were used in any EIAs that may have been prepared (not seen).

Earlier trends in PAHs concentrations may also be interpreted in light of the history of MHW dredging. Prior to 2006, the peak in dredging in MHW had been 1992. The high levels of mainly pyrogenic PAH found in October 1993 may be due to dredging disturbance in 1989-1992 at Texaco, Pembroke Dock, West Llanion Pill, PPS and Petroplus. ABP measured PAHs outside the mouth of MHW near the LU168 disposal site during 1995 (i.e. before 'Sea Empress') as part of the 'Orimulsion' work by National Power (pers. comm. ABP). Despite \% mud contents of only $0.2 \%$ to $0.3 \%$ in medium sand, the $\Sigma \mathrm{PAH}_{16}$ were from $2.55-3.15 \mathrm{mg} / \mathrm{kg}$, which were close to the range in considerably muddier stations inside MHW. For example, the mean $\Sigma \mathrm{PAH}_{16}$ concentration from berthing boxes in 2001-2007 was $3.61 \mathrm{mg} / \mathrm{kg}$. 
Although NMMP (2004) discussed dredging impacts at the national scale in some detail, no mention was made of detecting potential impacts at and near the dredged sites themselves, as opposed to the disposal sites. Environmental regulations are critical to ensuring resilience from potential stressors, but in the study commissioned by MHPA from Cardiff University (2012), complying with regulations was seen as burdensome by some respondents in the MHW energy sector. Neither MHPA (2011) nor Cardiff University (2012) comment on what went well and what did not (strategically, economically or environmentally) during the permitting process for the LNG developments. A complaint to the Commission of European Communities (CEC) has been raised by Friends of the Earth Cymru (FoE 2010), about permitting the new power station. The complaint alleges that CCW's advice was ignored by EA and that the separation of the assessment process into several pieces reduced its appropriateness for assessing in-combination impacts on the integrity of the SAC. Examples include impacts affecting seagrass (Zostera) and maerl (coralline algae) near South Hook LNG, and also playing off one impact against another such as the baseline shift between construction and operational phases, in contravention of Article 6/3 of the Habitats Directive (1992). The CEC is following up on the FoE complaint.

Other dredging and construction works

MHW has a long history of engineering works, including military, quarrying, land reclamation and construction (Little 2009). Many ship-building sites were located in MHW tributary inlets ('Pills'). The Neyland area has patches of very high PAH contamination (e.g. NMMP station 646 in June 1996 had $\Sigma \mathrm{PAH}_{22}$ levels of over 104 $\mathrm{mg} / \mathrm{kg}$ ). Mainly referred to 'Sea Empress' contamination, it also included pyrogenic material probably relating to historical ship-building and railways at Neyland (e.g. over $600 \mathrm{t}$ of treated timber was used to shore up Brunel Quay, and a coal-gas works was built in 1856). Castle Pill near Milford was a ship-breaking yard until the 1970s, Barnlake Point was an assembly yard in the 1980s, and Waterloo in lower Cosheston Pill had a range of uses including boat-building and waste disposal into the 1990s. More recently, land-based works including remediation of contaminated land and site preparation occurred from mid-December 2004 at South Hook, and from late summer 2003 at Dragon LNG. Jetty works at South Hook took place in autumn 2005 (Camplin 2008).

Westfield Pill was partially reclaimed for a marina facility from 1985, with initial spoil disposals behind a dam to the north. The dredging at the NYH marina uses a cutter suction dredger (CSD). Slurry is then piped to the disposal point offshore Neyland originally under Welsh Government licence. The slurry is discharged directly in ebb tidal streams, inevitably affecting the MHW turbidity field; it also may interact with turbulence from the twice-daily Irish ferry approaching Pembroke Dock (pers. comm. M. Maloney). The main CSD inputs were in 2005, 2007-2008 inclusive, and 2011 (Fig. 7). Compared to the MHPA dredging operations disposed at sea, the dredging in NYH marina is small-scale, yet the disposal of fine sediment into the water column means that transport and impacts of sediment contaminants are possible at greater distances from the point of disposal.

Chemistry measurements of the NYH marina sediments should have been determined prior to the authorisation of the site and during licensing of the ongoing dredging. Instead, no data are available on contaminants at the marina, although attempts were made to examine its effects using grain size and macrobenthos data (Camplin 2008). The NYH discharge potentially causes sedimentation, toxicity and lightattenuation effects. Spoil dispersion was studied by ETS (2002) and showed that fluorescent fine sediment tracer from the water column disposal point reached up-estuary to Garron and Lawrenny Pills. Tracer recoveries were skewed in a flood-tide direction, again supporting the STA result for inner MHW.

Using NLS' particle size data on benthic samples near NYH, the $<63 \mu \mathrm{m}$ fraction has been decreasing since peaks in 2005-2006 at three monitoring stations (Cascade Consulting 2011). They interpreted this as evidence that the CSD discharges from NYH which peaked 2007-2008 have had no effect on the seabed. If the dredge spoil suspension was not deposited in the vicinity, it follows that SPM was transported beyond the area. Fine silts and clays would not completely settle on the ebb tide, and so some SPM would then be transported upestuary on the flood. To demonstrate a lack of effects, monitoring should be conducted further afield and using appropriate chemistry methods.

However, the data could also be seen as evidence that during 2005-2006 sedimentation in the main axis of MHW had temporarily increased the fine sediment on the seabed prior to the NYH maximum discharges (Fig. 7). Detailed analysis by Cascade Consulting (2011) showed that $<20 \mu \mathrm{m}$ fractions (medium silt and finer) represented from $2 \%$ to $57 \%$ of the sediment, and are stratified in the settled sediment column. In their comparisons of surface $5 \mathrm{~cm}$ and $20 \mathrm{~cm}$ depths, the surface $<20 \mu \mathrm{m}$ fractions increased at half of the stations, decreasing elsewhere. This stratification is evidence of transient and patchy sedimentation on the seabed. It may reflect unusual mud deposition in 2006 resulting from MHPA dredging, with possible biological effects.

\section{Predicted biological effects}

In 2007, 2010 and 2012 the individual and total PAHs concentrations at almost all stations in MHW exceeded accepted sediment quality guidelines (SQG). The proportions of stations in excess of Threshold Effects Level (TEL) declined only slightly from $>87 \%$ in 2007 to $80 \%$ in 2012. For the metals $\mathrm{Cu}, \mathrm{Pb}$, and $\mathrm{Zn}$, in both 2007 
and 2012 the TELs were exceeded in at least $47 \%$ of stations, the proportion in excess only declining slightly from $>80 \%$ for $\mathrm{Cu}$ in 2007 to $73 \%$ for $\mathrm{Pb}$ in 2012. Given that TELs were exceeded by many contaminants at most stations, and could be seen as being over-protective, the Probable Effects Level (PEL) is more revealing, because the biological impacts are deemed probable in between $37 \%$ and $83 \%$ of field case studies examined by Environment Canada. The relevant data for PAHs in MHW are given in Fig. 10. Note that no metals or PCBs concentrations exceeded PEL guidelines.

In the 2007 survey, the two stations in Cresswell River were found to most frequently exceed the PEL concentrations for individual and total PAHs (9-12 occurrences). Additionally, all stations except those in Sandyhaven Pill and the lower Western Cleddau had from one to six PAHs in excess of the PEL, which implies that adverse biological impacts throughout MHW were reasonable to expect in 2007 (Fig. 10). In 2010 the peak exceedance of PEL for individual and total PAHs was in Angle Harbour (seven occurrences, one more than in 2007) and there were up to three other occurrences in the four stations in Pembroke River and Cosheston Pill. In 2012, only Pembroke River Upper had any PAH concentrations in excess of PEL (six occurrences). The exceedance zones occurred where flood-dominated tidal currents transport fine sediment from industrial reaches into tributary inlets with mud deposition at high tide slack-water, in high and inner flats (Van Straaten and Kuenen 1958). The absence of PEL exceedance elsewhere shows levels returning to the TEL.

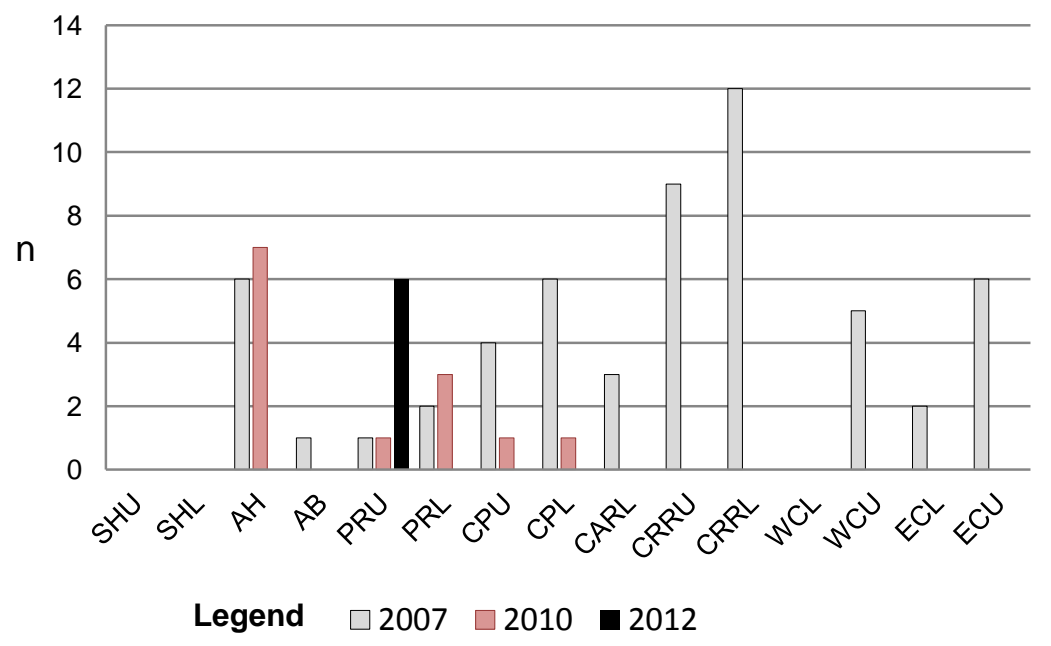

Fig. 10 Number (n) of occurrences in 2007, 2010 and 2012 of concentrations that exceed the Probable Effects Level (PEL sediment contaminant concentrations that have been associated with biological effects in between $37 \%$ and $83 \%$ of field case studies) [Notes: based on concentrations of alkylated $\mathrm{C}_{1}$ and $\mathrm{C}_{2}$ naphthalenes and phenanthrenes, on 15 individual parent $\mathrm{PAH}$, and on $\mathrm{SPAH}_{15}$. For the metals $\mathrm{Hg}, \mathrm{Cd}, \mathrm{Cr}, \mathrm{Cu}, \mathrm{Pb}$ and $\mathrm{Zn}$, and seven PCBs, none exceeded PELs. In 2010 the samples for SHU, SHL and WCU were not taken, and PCBs and metals were not analysed (see Fig. 1 for site locations) Sources: 2010 data - Fugro ERT; 2007 and 2012 data - pers. comm. NRW; PEL sediment quality guidelines www.ec.gc.ca]

Since the review by Little (2009), OSPAR has published guidelines for the NE Atlantic region, adapting the NOAA approach to European conditions (OSPAR, 2009 a-c). In none of the three years surveyed in MHW were any of the sediment contaminant concentrations in excess of the OSPAR-proposed Effects Range Median (ERM - the $50^{\text {th }}$ percentile of sediment contaminant concentrations that have been associated with biological effects). The OSPAR Effects Range Low (ERL - lower tenth percentile of contaminant concentrations associated with biological effects) is similar to the TEL, but being set at higher concentrations, is more discriminating between stations.

The relevant OSPAR ERL data for PAHs and metals in MHW are shown in Fig. 11; there were no PCBs data in excess of ERL guidelines. These values show a general decline in the number of contaminant concentrations >ERL from 2007 through 2010 to 2012. However, there were variations along the axis of the estuary that agree very closely with the trends described for the total PAHs, namely the pulse of contaminated SPM passing up-estuary. After declining from 2007 to 2010, the number of stations with concentrations $>$ ERLs showed resurgence in 2012 at most upper-estuary locations WCU, WCL, CARL, ECL and ECU (Fig. 1). Uniquely, at PRU the number of contaminants >ERL increased from 2007 to 2010, with real effects on bioaccumulation (Langston et al. 2012b; see below).

The SQG approach suggests not only macrofaunal impacts in 2007 but also some recovery in the next six years. This duration is longer than implied in EIAs and agrees with reviews, including in MHW, finding some benthic impacts of dredging lasting up to a decade in berthing boxes and in fine sediments in low-energy areas (Newell et al. 1998; Hebog 2006; Warwick 2006). 


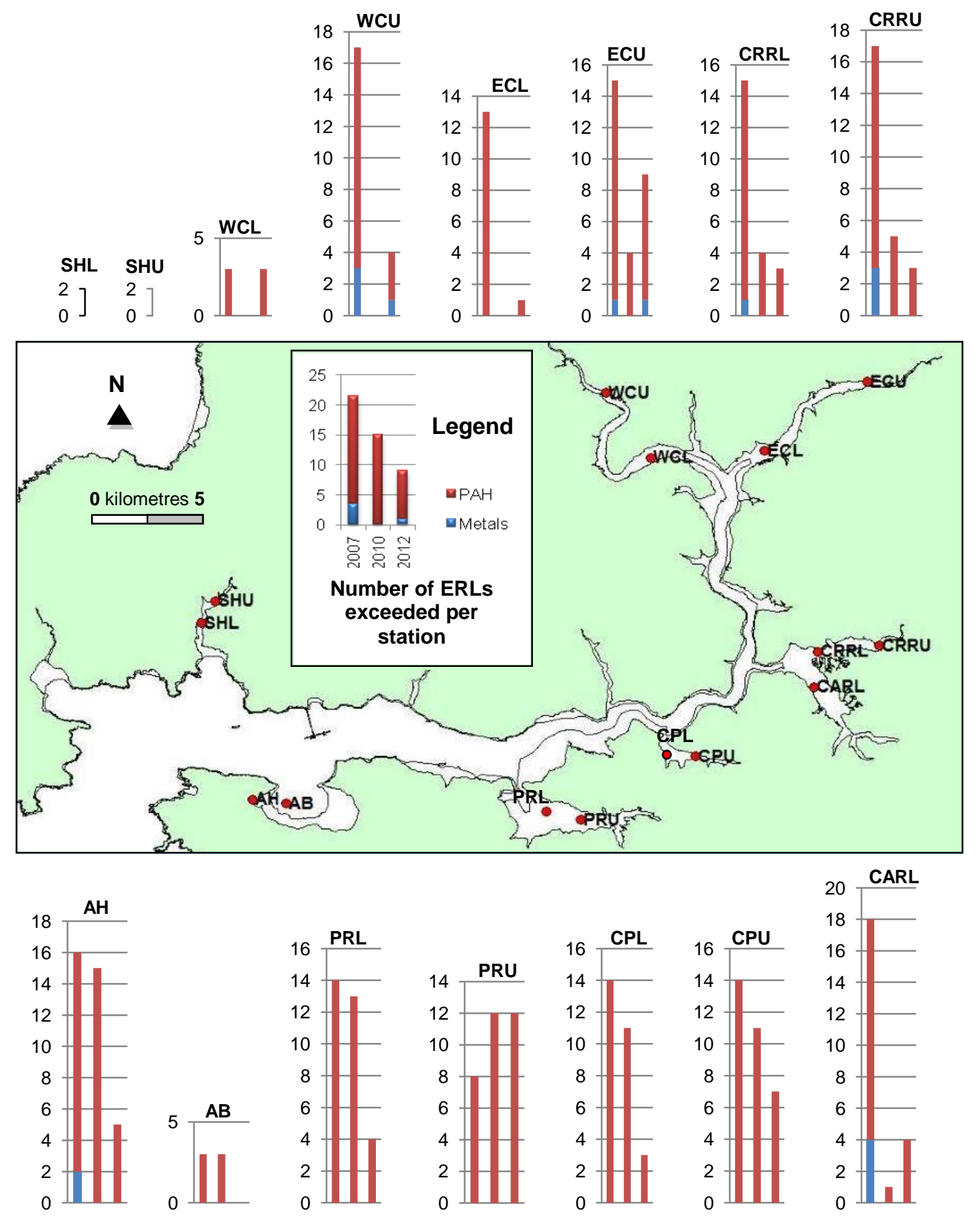

Fig. 11 Number of occurrences in 2007, 2010 and 2012 ( $\mathrm{L}$ to R) of concentrations exceeding Effects Range Low (ERL lower tenth percentile of contaminant concentrations associated with biological effects) [Notes: based on alkylated $\mathrm{C}_{1}$ and $\mathrm{C}_{2}$ naphthalenes, phenanthrenes and on 11 individual parent $\mathrm{PAH}$, the $\Sigma \mathrm{PAH}_{11}$, the metals $\mathrm{Hg}, \mathrm{Cd}, \mathrm{Cr}, \mathrm{Cu}, \mathrm{Pb}$ and $\mathrm{Zn}$, and seven PCBs (none >ERLs). In 2010 samples were not taken at SHU, SHL and WCU, and PCBs and metals were not analysed. See Table 1 for abbreviations used [Sources: 2010 data - Fugro ERT; 2007 and 2012 data - NLS; ERL sediment quality guidelines, OSPAR (2009a-c) - www.ospar.org/.]

Observed potential biological effects

\section{Wetland birds}

Peak average monthly counts of waterbirds in MHW 1999-2013 were reviewed using the Wetland Bird Survey (WeBS). In this period the winter of 2005-2006 was a peak in numbers for species that often reach nationallyimportant numbers in MHW: wigeon Anas penelope, teal A. crecca, golden plover Pluvialis apricaria, and 
greenshank Tringa nebularia. Since the peak in 2005-2006 all of these species have declined in MHW. Neither wigeon nor golden plover have yet recovered their peak numbers, and the teal and greenshank numbers were not regained for five years. The total waterbirds counted in MHW as well as the totals of MHW's nationallyimportant bird species also decreased after 2005-2006 (Fig. 12, WeBS reports and pers. comm. A. Haycock).
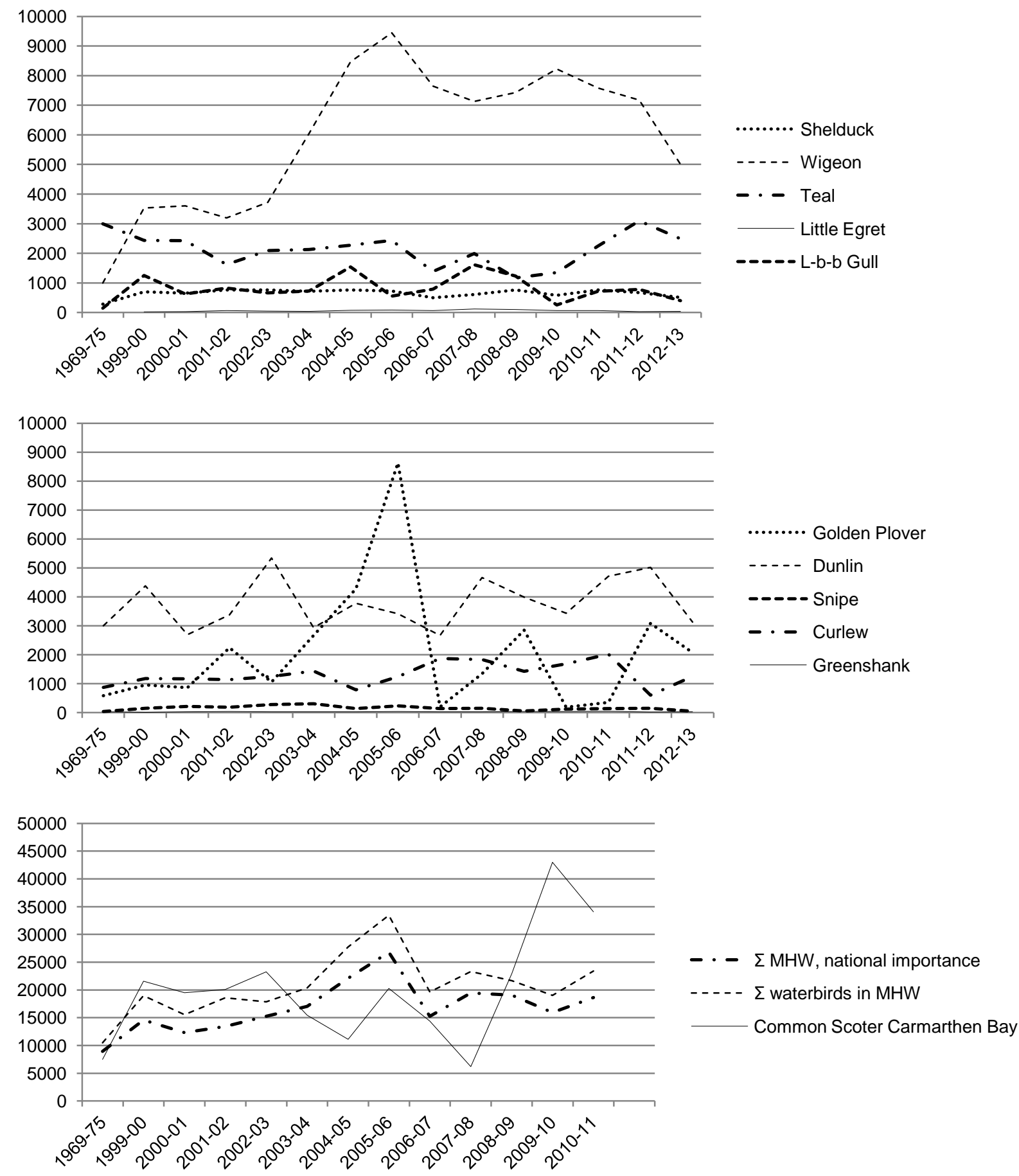

Fig. 12 Monthly peak count data for selected waterfowl species in MHW 1969-2013 (top and middle); total birds in MHW and nationally-important species in MHW1969-2011, noting that common scoter Melanitta nigra in Carmarthen Bay would not be affected by operations in MHW, implying more widespread causative factors (bottom) [L-b-b gull refers to lesser black-backed gull Larus fuscus; Source: WeBS data for Cleddau Estuary; Prater (1981); pers. comm. A. Haycock (2014)]

The MHWESG review of wildfowl and waders peak counts by Haycock (2013) shows that the declines of many species in MHW since the 2005-2006 peak should be put in the context of longer running data sets since high levels in the 1980s, and also of national and of international trends. National WeBS data have shown declines since winter 2005-2006 for most of the above-mentioned species, and in addition pintail A. acuta, 
gadwall A. strepera, shoveler A. clypeata, lapwing Vanellus vanellus, and snipe Gallinago gallinago. This implies national causes, such as drought in winter in England which can push birds westwards; water levels and ice conditions at inland sites affect the numbers of birds wintering on estuaries. Many of the trends in wintering wetland birds in MHW are the result of international factors, principally the 'short-stopping' during mild winters, whereby birds stay farther east in muddy estuaries with better foraging. Conversely, its westerly location means that MHW sometimes has higher waterbird numbers when winters are hard further east.

In this case, however, the harshness or mildness of winter weather is not thought to be entirely responsible: colder than average winters occurred in 2004-2005, but not again until 2008-2009 with neither of these winters being the MHW peak count. MHW had sustained wintering waterbird numbers relatively well until the 20052006 winter, in contrast to national trends showing that $70 \%$ of native wildfowl species wintering in the UK had been in long decline since before 2000 (Austin et al. 2014). In addition, the pattern is complex because the winters since 2009-2010 each have had record-breaking cold, mild, wet, and dry conditions in some months.

Haycock (2013) does not particularly highlight 2005-2006, although peak numbers that winter were boosted by large influxes of wigeon and golden plover. For wigeon, 2005-2006 was the highest ever count in MHW with the exception of winter 1986-1987, when extreme and prolonged cold weather in eastern UK pushed birds southwest. Local factors such as oil spills may have affected numbers of wintering wetland birds in MHW. There was a low-tide count in winter 2005-2006, and this showed more than 1,000 birds each for wigeon, curlew Numenius arquata, golden plover and dunlin Calidris alpina. The previous low-tide count was 19971998, and the 2005-2006 redshank Tringa totanus numbers in Angle Bay may have increased since then due to the effect of oil in Angle Bay after the 'Sea Empress' in February 1996 (Musgrove et al. 2007, citing Armitage et al. 1997). However, MHW's largest oil spill did not produce lasting perturbations in total numbers of birds (Haycock 2013). In contrast, in the Firth of Forth, shelduck and dunlin were adversely affected by refinery effluent discharges (Elliott and Griffiths, 1987).

Dunlin numbers were reduced temporarily in winter 2006-2007. Both redshank and dunlin have since recovered to more typical numbers in MHW. Dunlin abundance in 2006-2007 was the lowest since 1987-1988, and the highest peaks were in 1996-1997. Dunlin in Pembroke River during the 2000s occurred at about half the numbers typical of the 1990s. Numbers of curlew have also declined since 1989-1990 in both MHW and Burry Inlet. Although golden plover seldom feed intertidally, in 2006-2007 there was a complete absence of birds that in turn reduced the total wader counts that winter (Haycock 2013). Teal counts were lowest in 2008-2009 after the national UK peak in 2005-2006, but have since climbed again to 2011-2012. It is likely that the improved protection of mainland European sites from hunting pressure has encouraged more birds to winter on the continent. Greenshank counts in MHW ranked about fifth in Britain until 2006-2007, but have fallen away since. Little egret Egretta garzetta were lowest in number in 2005-2006 after steadily climbing for two decades across the southern UK. With all the above patterns, poorly-understood interactions and inter-annual variability from local to international scales were at work. Yet it is clear that the years 2005 to 2007 are pivotal in MHW for many of the important species counted. The declines after 2005-2006 in some bird species may result from SPM disturbance by dredging during 2006 that perhaps reduced intertidal bird foraging success.

Shelduck Tadorna tadorna typically forage for mudsnails (Hydrobia ulvae) in surficial sediments. The counts of shelduck were at a minimum in 2006-2007, the lowest count since 1984-1985. Burry Inlet shelduck counts have also been lower recently, although not those in Wales or UK as a whole. However, shelduck showed biggest winter reductions in Pembroke River in 2006-2007, and in spring 2007 showed the largest drop in numbers of broods between successive breeding seasons since MHWESG surveys of breeding shelduck began in 1991 (Haycock 2013). Breeding shelduck maintain a feeding territory, and so the brood is a good monitoring unit tied to the quality and size of foraging areas near the nest site. A thin layer of uncontaminated mud would not necessarily put shelduck off an area, because surficial fauna such as mudsnails would survive by burrowing upwards after deposition of mud. Shelduck censuses show a drop in numbers of broods in, or usually one year after, the years of high dredging activity (1992, 1997, 1998, 2002, 2006, 2008, 2010 and 2011, Fig. 13); of these, only 1997 and 2008 had no drop in number of broods (PCNPA 2014). MHW shelduck broods fell to only five in 2012 and 2013 from peaks of >20 recorded until 2006 (Fig. 13). There was a steady decline in brood size, from averages of 7.7 in the first, to 5.3 in the second decade of monitoring since 1991. Instead of being affected by oil spills (e.g. 'Sea Empress'), the shelduck trends support the hypothesis of reduced forage quality after mud deposition.

Pembroke River is one of the most important sub-sites in MHW, typically supporting two-thirds of the wigeon, half the dunlin, one third of shelduck, and one fifth of the curlew. The top-ranking 8 species except oystercatcher have all declined since the 1980s in Pembroke River. However, wigeon were increasing steadily between 2003 and 2006, especially in Pembroke River. Dredging is mentioned as a possible factor in influencing birds since 2006 (Haycock (2013), for example if silt had settled thickly upon seagrass (Zostera) beds. Then, after further dredging in Pembroke River 2008-2011 and power station commissioning in late 2012, the wigeon arrived as usual in September 2012, but $c a$. 3,000 fewer than previously. They departed earlier than 
is typical for their movement to other parts of MHW in search of fresh grazing. Haycock (2013, page 37) suggested the unusual situation in Pembroke River for wigeon in 2012:

"...may have been a one-off event; it may be caused by events away from the estuary; there may have been some disturbance that kept birds away, or it may indicate some change in the food supply in Pembroke River".

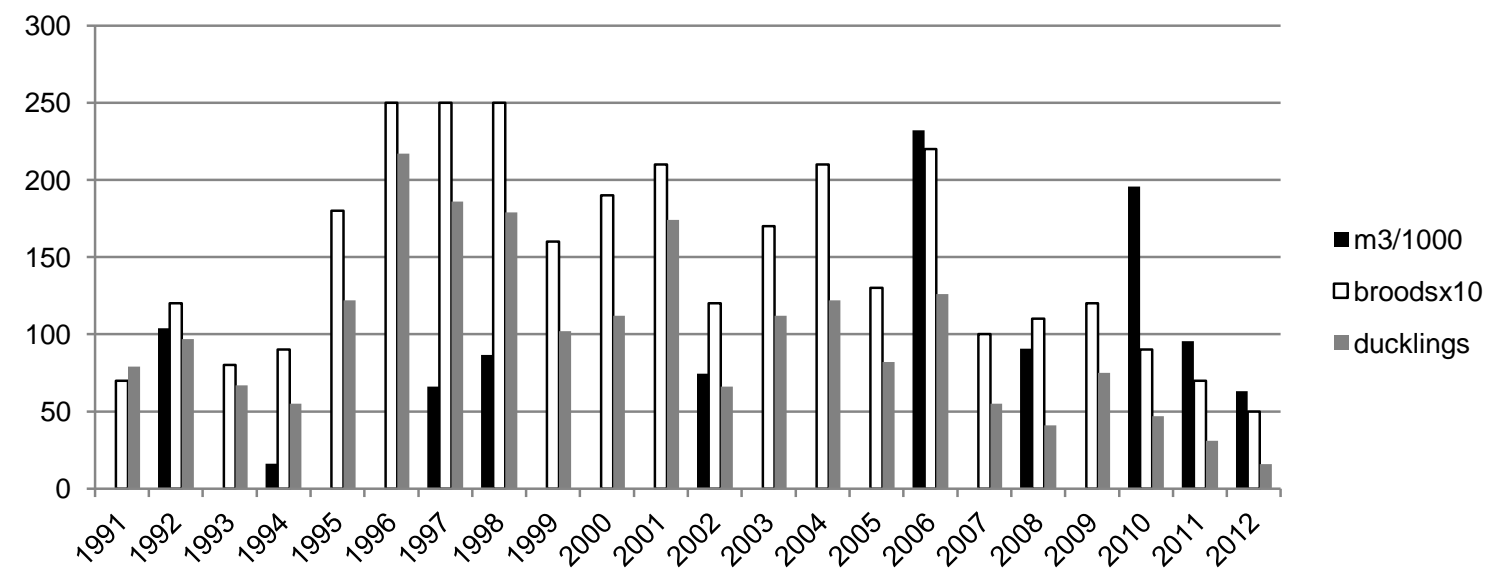

Fig. 13 Dredge spoil volume $\left(\mathrm{m}^{3} / 1000\right)$, shelduck broods (x10) and duckling numbers [Source: MHPA (2011); PCNPA (2014)]

\section{Other biota}

The abundances from independent biological surveys underway in MHW are shown for starfish at West Angle Bay in ESM-Fig. 1 (Crump 2013); for limpet Patella vulgata at Dale Fort in ESM-Fig. 2 (Archer-Thomson 2013); and for grey seal Halichoerus grypus live pup births just outside MHW in ESM-Fig. 3 (pers. comm. A. Bunker; Boyle 2012). In several long-term data sets, the year 2007 was the minimum data point of the decade. Limpets and starfish A. gibbosa showed declines beginning slightly earlier, in 2004 and 2006 respectively. Grey seal pups showed an erratic decline since peaks in the 1990s. However, the probability of the minimum abundances in a wide range of species occurring in 2007 by chance was $p<0.01$ ( 9 degrees of freedom). The numbers of biota fluctuate with sediment contaminants and in response to other factors, and since contaminant body burdens were not determined, this statistically significant result does not prove cause and effect.

Sediment disturbance near the mouth of MHW would have resuspended TBT, PAHs, metals, and other contaminants into an ordinarily low turbidity part of MHW. The background SPM concentrations in August 2006, already four times the previous background, were from 55.9 to $61 \mathrm{mg} / \mathrm{l}$. With one exception, the MHW entrance is not predicted by STA to be affected by sediment transport from inside the estuary (McLaren and Little, 1987). The exception is the south channel of MHW ebbing from Angle Bay to offshore West Angle Bay. In August 2006, compared to the rest of lower and mid-MHW this ebb-dominated pathway had higher background SPM concentrations of from 63.1 to $67.8 \mathrm{mg} / \mathrm{l}$ (pers. comm. M. Maloney).

This observed turbidity contrast between the north-central and the southern sides of the entrance to MHW was just as would be expected from the ebb-flood flow channel separation, and as suggested by the STA (McLaren and Little 1987). It is likely that construction and dredging increased the turbidity levels in the lower and mid-reaches of MHW in 2006. If this were so, and if contaminated SPM were a cause of the above dips in monitoring trends in 2007, then the clear-water biota of MHW may not necessarily be pre-adapted to contamination to the degree sometimes assumed by licensing agencies and in EIAs.

\section{Bioaccumulation surveillance}

The bioaccumulation findings for PAHs in the two surveys by Langston et al. (2012b) show direct parallels in concentration trends in mussels at several stations between March 2008 and March 2010 that are consistent with the changes in sediment PAHs and metals concentrations reported in the present study. Whereas concentrations of anthracene, fluoranthene and phenanthrenes in mussels increased (t-test, $p<0.05$ ) at all sites studied by Langston et al. (2012b), the change from 2008 to 2010 in means of $\Sigma \mathrm{PAH}_{17}$ concentration was not statistically significant. However, the mussels at Angle (near AH) and Pennar (near PRU) showed order of magnitude increases in uptake of individual and $\Sigma$ PAHs (Fig. 14 top), perfectly reflecting the $\Sigma$ PAHs in nearby sediments at AH, PRL and PRU between late 2007 and 2010. Mussels receive this burden by filtering particles from the water, and this suggests SPM transport as a contaminant pathway. 
For ragworms, which showed an order-of-magnitude less PAH bioaccumulation than did mussels, mean concentrations of total PAHs, fluorene, fluoranthene and phenanthrenes decreased overall $(p<0.05)$ between the autumns of 2007 and 2010 (Fig. 14 bottom). As would be expected from the selection of ragworm as an indicator species for contaminant uptake from deposits of fine-grained sediment, this decrease is in line with the sediment PAH decreases reported in the present study in almost exactly the same time interval.

Exceptions to this general decrease in uptake by ragworms were (1) chrysene which increased across the estuary, and was the only PAH to increase in ragworm at Angle, and (2) benzo(b)fluoranthene which increased upriver in ragworm of the Daucleddau and at Pennar. These changes agreed with sediment PAH increases respectively at $\mathrm{AH}$ (chrysene), PRL and PRU (benzo(b)fluoranthene) in the present study. The clear increase 2007-2010 in the concentrations of the high molecular-weight PAHs in ragworms is a likely result of resuspended sediment contamination. These heavier PAHs of a predominantly pyrogenic nature are less watersoluble so that their residence time in sediment is longer than the lighter PAH.

For PCBs, Langston et al. (2012b) found no significant gradients in their uptake by mussels estuary-wide or between years. In contrast, they found ragworm samples near Waterloo and Pennar to be more contaminated, similar to the present sediment surveys where one or both Cosheston Pill stations (CPL, CPU) were polluted by PCBs (in addition to PRL and other innermost stations). Waterloo is a former fishing and boat-building quay, scrap yard and landfill. The overall increase in total PCBs in both ragworms and sediments from 2007 to 2010/12 was common to both projects. The PCB congeners 028 and 052 dominated in mussels across the estuary in 2010, and PCB 028 alone was dominant in 2012 sediments.
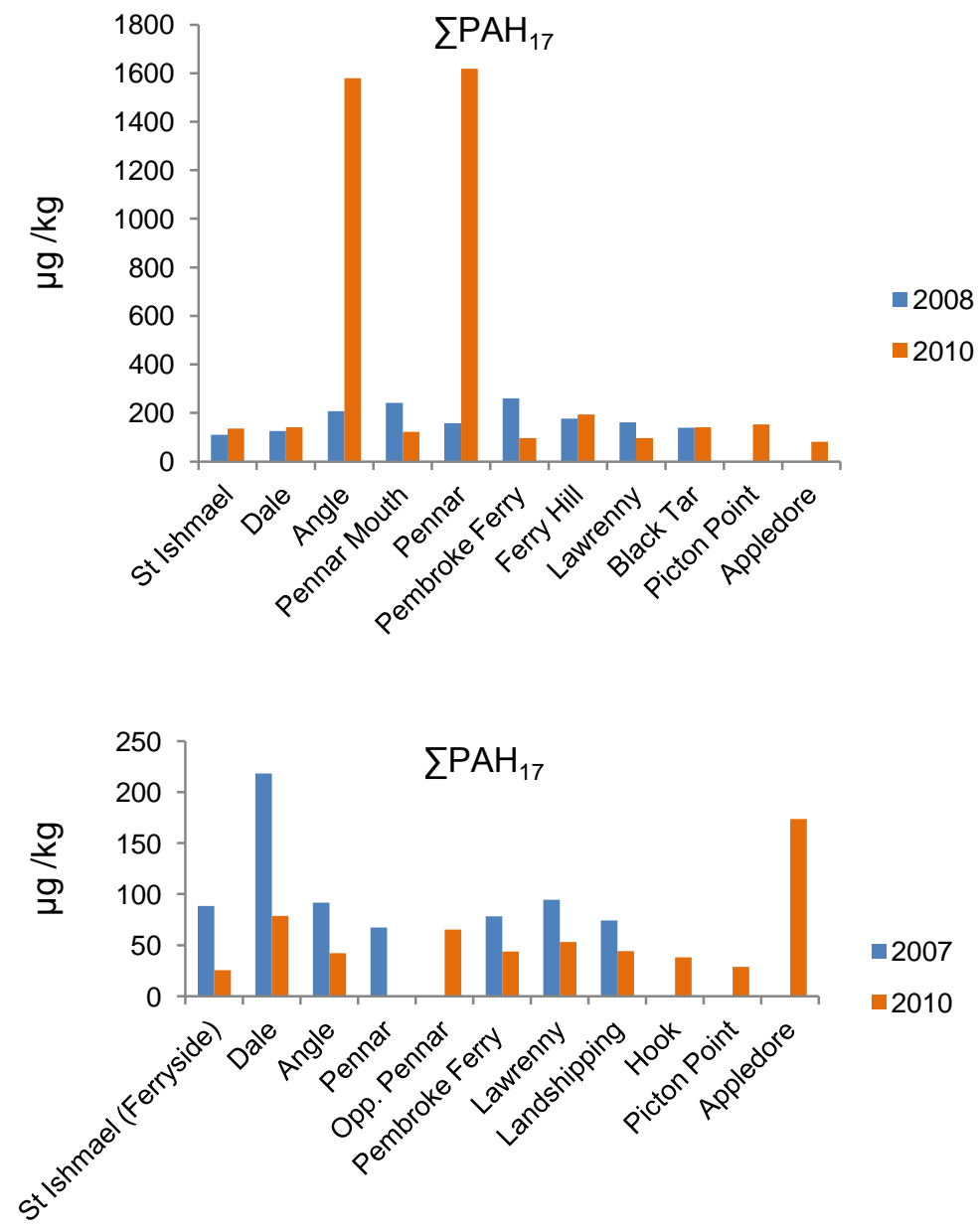

Fig. 14 Bioaccumulation of $\Sigma \mathrm{PAH}_{17}$ in mussel (top) showing enrichment at Angle (AH) and Pennar (PRU) in 2010, and in ragworm (bottom) showing generally decreased concentrations in 2010; note differing y axis scales (see Fig. 1 for MHW site locations) [Source: Langston et al. (2012b)]

For TBT, Langston et al. (2012a, b) predicted that levels would fall from 2007-2010 following the global ban in 2008, but their 2010 survey may have been too soon to detect decreased TBT levels in biota. In contrast, the sediment surveys did show TBT decreases between 2007 and 2012 at five stations distributed along MHW. Mussels (and cockles Cerastoderma edule) were rather better indicators of metals bioaccumulation than were 
ragworms, as mussels also had been for PAHs. Nickel (also Co, in cockles) often showed the highest uptake, among the upper $25 \%$ of UK levels, and Ni was locally enriched in ragworms at Pennar. Generally, the metals showed enhanced uptake up-estuary in both bioaccumulation surveys, thought to be due to geological sources (e.g. Pembrokeshire coalfield outcrop), lower salinities and hence less competition from complexation by chlorides (Langston et al. 2012b). Nevertheless, biological uptake of Hg decreased significantly 2008-2010 in all species $(p<0.05)$, which agreed with the decreases for $\mathrm{Hg}$ in sediment 2007-2012.

Although the list of target PAHs in biota was not the same as those used in the sediment studies, there is very good general agreement between the sediment and tissue data. The dramatic PAH signal in mussels at Angle and Pennar, the overall downward trends for PAH in ragworms, and the above linkages between biota and sediment trends for PAHs, PCBs, TBT and $\mathrm{Hg}$ are all further independent support for the hypothesis that construction disturbance and resuspension of historically-contaminated sediments are involved. The CSD disposal at Neyland and TSHD spillage from maintenance dredging may be significant sources of secondary contamination of surficial sediments and biota in MHW. The observed distances from dredging sources of the PAHs bioaccumulation by biota and the timescales demonstrated by Langston et al. (2012b) are greater than those predicted in the EIA by RWE npower (2007). The EIA predicted that high rates of tidal flushing through MHW would reduce the bioavailable contaminants to background within a few tidal cycles.

The available data showed a pattern and timing of significant PAHs enrichment that were consistent with the timing of contaminant aerial inputs, runoff, and remobilisation during known periods of sediment disturbance; notably during construction of the power station in 2008-2011. The pathways from the PAH sources in the midreaches of MHW to the invertebrate receptors in Pembroke River and Angle Bay were in good agreement with the sediment chemistry trends 2007-2010, and with the STA pathways on flood-tides (Pembroke River) and ebb-tides (outer Angle Bay).

\section{Overall interpretation}

A review by Eggleton and Thomas (2004) showed that fine-grained sediments act as contaminant sinks due to their high surface area and sorptive nature. If binding is sufficiently strong and irreversible, fine sediment is an important reservoir that reduces toxicity to aquatic biota. However, disturbance involving mud resuspension releases pore water causing Eh (redox potential) and $\mathrm{pH}$ changes that can accelerate desorption of contaminants, profoundly affecting their bioavailability. For metals there is some controversy over how acutely toxic this lability can be, whilst for PAHs there is evidence that bioavailability increases. Although the disposal sites offshore have been studied, and Hebog (2006) documented effects at the MHW dredging sites themselves, the wider effect of sediment resuspension inside MHW has not been properly studied.

In the context of using EIA to avoid or minimise adverse impacts of LNG developments, it was agreed to use directional drilling for the PPS gas supply pipeline under MHW, and under the Western Cleddau for the export line to the east. Such drilling avoids disturbing fine sediments that would occur by cutting a cheaper pipeline trench. Construction impacts and especially in-combination impacts from repeated or concurrent dredging are difficult to estimate in EIAs. All EIAs should first characterise the baseline levels of stressors (e.g. SPM from tidal currents, storm waves, vessel movements, fishing, bait-digging, saltmarsh erosion, etc), but seldom do this fully. The present work has recognised potential effects in MHW during the development of LNG and power plants, and of disposals from NYH marina licensed originally by the Welsh Government and since 2013 by NRW. In addition, questions have been raised recently about the effectiveness, independence and transparency of statutory consultation by NRW since the creation of a single body from CCW and EA in Wales (Lewis 2015).

Sediment influx from the MHW drainage basin could be expected to affect contaminant levels in muddy sediments from 2007-2012. The effect could be positive in the case of dilution by clean incoming sediments or negative when the influx is contaminated. Partly due to the economic downturn since 2008 that has generally reduced building activity and usage of road fuels, declining contaminant inputs in runoff from the MHW catchment may have contributed to the observed decrease in sediment and biota concentrations. Nearly $70 \%$ of mainly rural service stations have closed since 2000. According to the Office of National Statistics (ONS) there was a ca. 8\% fall in sales of road fuels in Pembrokeshire and the UK between 2007 and 2011 (DECC 2013).

Alternatively, in the negative case, increased pollution may have occurred due to the recent unusually wet summers and cold winters. 'The Economist' during 2013 reported long-term ONS data suggesting that pot-hole erosion in asphalt has increased due to road repair budgets being cut across Britain, and that a drop in the use of garages for parking overnight had occurred, due to the increasing size of cars. As a result of a combination of the weather, the state of repair of roads and the declining use of garages, contaminants in road runoff have likely increased nationally. Together with the construction in MHW of two new LNG plants and power station (PPS), it might be expected that PAH inputs and concentrations would have increased over the 2007-2012 timeframe.

Instead, concentrations have generally decreased between 2007 and 2012. Specifically, they only increased in those few areas and for some hydrophobic compounds where the surface 1-2 cm sediments were contaminated toward the end of LNG-related activities, by NYH marina-related disposals and by spillage from 
dredging. Most recently, inner reaches of MHW were partially re-contaminated by a pulse of SPM moving on flood transport pathways on timescales of <2 years (2010-2012), and also by ongoing PPS and marina dredging.

However, in either the above positive or negative case, inputs from a mix of rural and urban tributary catchments of varying discharges are unlikely to have affected all of the tributaries simultaneously. The only simultaneous source in all the drainage basins would be atmospheric deposition, typically dominated by petroleum from domestic and vehicular emissions. As with $\mathrm{NO}_{\mathrm{x}}$ and particulates, the PAHs inputs may be rising in spite of improved vehicle engineering because diesel vehicles have increased as a proportion of the UK fleet from $14 \%$ in 2001 to $36 \%$ in 2014 . This has been encouraged by government tax incentives designed to reduce $\mathrm{CO}_{2}$ emissions to mitigate climate change. There is also some indication of a link between PAH concentrations and fingerprints in the sediments of MHW and atmospheric inputs from the Buncefield tank farm fire in December 2005 and into 2006 (Little and Galperin in press; Little et al. 2015; DEFRA 2014).

However, the contaminant patterns in MHW appear to be driven by activities down-estuary. SPI captured in 2012 provided independent evidence of cumulative dredging disturbance (Germano \& Associates, Inc. 2013). Examples of disturbance on Milford Shelf and off Angle Bay show mottled sediment with a chaotic texture. Although some mottling occurs naturally in reduced, bioturbated silts, there are signs that subsurface material has been disturbed anthropogenically. About 30 stations showed possible visual impacts of disturbance, all but a few of them in areas of construction and dredging extending from South Hook LNG to Dragon LNG terminals.

The interpretation is supported by SPI of sediment structure (i.e. drivers of physical disturbance), sediment forensics (i.e. sources of chemical stress) and bioaccumulation effects (i.e. impacts on biological receptors). The connecting pathways were first predicted by STA (McLaren and Little 1987). The pathways are underpinned by estuarine transport processes illustrated by dredge plume-tracking and fluorescent sediment tracer studies. These showed net transport rates from two weeks to one year to traverse the axial length of MHW, and so the contaminant concentration changes in $<2 \mathrm{~cm}$ surficial sediments are commensurate with freshly-deposited surface layers.

Before the financial crisis, the pronounced peak in PAHs concentrations in 2007 exceeded SQGs that would reasonably predict adverse biological effects. Dips in abundance have been observed almost simultaneously in several invertebrate and vertebrate species. The contamination resulted from a combination of factors: long, albeit intermittent periods of construction of LNG-related plant, various dredging operations, runoff, and fallout possibly including from Buncefield. The combination may explain why possible impacts were detected near and outside the entrance to MHW, as well as in the innermost reaches where STA predicts effects.

Inter-disciplinary work in MHW by independent researchers clearly shows the value of STA which first helped explain contaminant distribution in 1987. Geochemical markers identified between 2007 and 2012 are effective sediment tracers, confirming sediment and contaminant transport patterns that were predicted by STA and reflecting classic clay accumulation models. The STA combined with the inter-disciplinary work generates falsifiable hypotheses to assess long-range transfer and long-term fate of water and air pollutants arising from chronic inputs and major events (Little and Bullimore 2015; Little et al. 2015; Little and Galperin, in press).

\section{Conclusions}

PAH and other contaminants: Monitoring of MHW sediment contaminants in 2007-2012 benefitted from using the same field sampling methods, personnel, time of year and similarly advanced analytical techniques. Concentrations were elevated throughout MHW in 2007 after contaminated sediments were disturbed by construction and dredging operations, which had peaked in 2006, and also due to aerial inputs and runoff. Since then, from 2007 to 2010 most of the sediment (and ragworm) contaminant concentrations have generally decreased by dilution (and depuration). The changes 2010-2012 suggest re-suspension and transport of a pulse of historically PAH-contaminated sediment moving up-estuary. Concentrations 2010-2012 have increased only when sediment has continued to be disturbed and where sediment transport pathways lead to depositional sinks. The conclusions drawn were similar not only for PAHs but also for metals, and successfully extended the environmental forensics work to consider the impacts of dredging and construction of two LNG terminals and a power station. Survey value was also increased by comparing sediment contaminant data to results from biological and bioaccumulation monitoring.

Sediment quality guidelines: Many of the PAHs exceeded SQGs particularly in 2007, and this is likely to have had biological effects in MHW. Downturns in abundances among several potential invertebrate and vertebrate receptors also occurred around 2007 at a probability level unlikely to have occurred by chance across all datasets. Recovery to below SQG levels of effect took place at most stations from 2007 to 2010, although high predicted PAH risk levels remained at Angle Harbour and Pembroke River. Due to the above-mentioned pulse, some upper MHW stations again exceeded SQG thresholds in 2012. In conclusion, the impact and predicted recovery after dredging agree with previous findings on benthic recovery of from three to 10 years.

Wetland birds: The winter counts of 2005-2006 showed peak numbers for those species often reaching nationally-important numbers in MHW: wigeon, golden plover, greenshank and teal. All of these species have 
declined since. Dredging was a probable factor due to silt from 2006 operations settling where shelduck forage for mudsnails in surficial sediment. Shelduck had their biggest winter decrease in Pembroke River in 20062007. In spring 2007 the largest drop in numbers of broods between successive breeding seasons was noted since the MHWESG breeding shelduck survey began in 1991. In 2010-2011 contaminated silt from dredging operations in the power station channels settled in Pembroke River, as predicted in the power station EIA. This adversely affected foraging quality for both wigeon (seagrass) and shelduck (mudsnails). MHW shelduck broods fell to only five in 2012 and 2013 from peaks of > 20 recorded until 2006; there was also a steady decline in brood size. The wigeon arrived as usual in September 2012, at the time of power station commissioning, but then they departed earlier than is typical for their movement on to fresh grazing within MHW. Their numbers were 3,000 fewer than previously.

Bioaccumulation: No overall change in PAHs uptake by mussels was seen across MHW during 2008-2010. The exception was an order of magnitude increase in concentrations in mussels at Angle (Harbour) and Pennar (Pembroke River). In contrast, an overall downward trend for total PAHs in ragworms was seen 2007-2010, except for higher-molecular weight PAHs at Angle, Pembroke River and some upriver stations. There are simultaneous trends in some biota and nearby sediment contaminants for PAHs, PCBs, TBT and Hg. This synchrony supports the hypothesis that resuspension of historically-contaminated sediments by construction works and possible spillage from dredging operations and marina disposal may be root causes of SPM effects on filter-feeding mussels near the construction activities, and settled sediment effects on ragworms further away. These effects occurred further away than the $400 \mathrm{~m}$ radius predicted in EIAs to be affected by primary (loss of seabed) or secondary (plume sedimentation) impacts. Bioaccumulation in receptors in fact represents a tertiary effect that could adversely affect animal and human consumers of cockles and winkles in Angle Bay, Pwllcrochan and Pennar Flats, and especially Pembroke River for the native oyster fishery.

Recommendations: For development proposals requiring EIA that fall within marine SACs such as MHW, a Habitats Regulations Assessment (HRA) is also required; Appropriate Assessment (AA) is one stage in the HRA process. For the various proponents' linked and overlapping LNG projects and the stages in their review to be environmentally defensible and acceptable, the EIAs and supporting monitoring data should be better coordinated and openly published in line with good environmental practice and with UK and European laws. The above weight of evidence from independent chemistry and biological monitoring in MHW has shown reasonable doubt concerning the predictions that there would be no significant adverse impacts of the LNG projects developed and operated in combination. The scientific evidence tends to agree with a complaint lodged with the CEC that the AAs performed for recent LNG projects were fragmentary and incomplete, and in some cases where there was an absence of adequate knowledge, they also failed to apply the precautionary principle. The following recommendations should be considered in future monitoring and EIAs.

Firstly, improved collaboration between monitoring stakeholders would minimise variations in aims, sites, timing, methods and laboratories. All analyses should be routinely replicated, with adequate LODs. The PAHs analysed have seldom included alkylated PAHs, and the metals suite has changed over time. In 2007 and 2012 only 6 sediment trace elements were reported, compared with 9 trace and 5 major elements in 1982, 1984 and 1994, albeit using different extraction methods. In coring studies in 1986, 22 trace and 9 major elements were analysed including 7 rare earths (some arising from fuel cells, batteries and turbines and increasingly likely to enter waste streams). A repeat of the 1986 contaminant and core-dating study is highly recommended.

Secondly, STA and visual SPI surveys helped to determine the biota's exposure to mobile contaminants and the correct apportionment of impacts to sources in MHW. The rates of physico-chemical sedimentary processes during engineering works were established, and assessments made of ecological stressors in combination with oil spills, chronic effluent or non-point sources; an approach that could be used more widely in UK waterways.

Thirdly, biological monitoring varies from local projects to those with international reach (e.g. WeBS), yet often not in enough detail at estuary or sub-estuary scales to distinguish local, national and international pressures. Because this may be more generally true of monitoring, it may be questionable whether much value is added. There is often insufficient awareness of stressors, little evidence for them collected in the field, and inadequate time invested in standing back to look at the evidence for causal linkages. This can be tackled if multi-disciplinary surveillance looks into potential drivers of change. Proof is difficult to establish, but attempts should be made to identify cause and effect, in order to generate falsifiable hypotheses and to make useful modifications to monitoring.

Fourthly, in many EIAs, the baseline contaminants are crudely summarised, and therefore new data collected during the EIA can only be judged simplistically to be within 'normal' ranges for the site, or not. This is crude because it does not consider an increasing baseline or adequately predict cumulative and indirect impacts such as are apparently occurring in MHW. This is complicated by separate regulatory bodies being responsible for stressors working in-combination (e.g. maintenance and marina dredging). Therefore, independent and comprehensive reviews of development proposals are essential if the favourable status of features of nature conservation importance is to be achieved and sustained. 


\section{Acknowledgments}

Funding was by MHWESG, the 2010 data were provided by Fugro ERT, and the 2007 and 2012 data by NRW, as was the field team in all three years. We thank Cpt. M. Andrews, J. Archer-Thomson, A. Bunker, M. Camplin, D. Carey, R. Crump, J. Germano, M. Hayn, D. Levell, and M. Maloney. Independent studies were by WTSWW and the FSC at Dale Fort and Orielton. British Oceanographic Data Centre supplied CSEMP data from the Clean Safe Seas Evidence Group. We thank A. Haycock and team for data from WeBS by British Trust for Ornithology, Royal Society for the Protection of Birds, and Joint Nature Conservation Committee (on behalf of Natural England, NRW, Scottish Natural Heritage and Department of the Environment Northern Ireland), in association with Wildfowl and Wetlands Trust. This is the accepted version of the manuscript, 30 November 2015, the final publication is at link.springer.com: http://link.springer.com/article/10.1007/s10661-015-5017-1

\section{References}

Archer-Thomson, J. (2013). The continuing story of the limpets of Frenchman's steps. Porcupine Marine Natural History Society Newsletter, 34, 22-27.

Armitage, M. J. S., Burton, N. H. K., Rehfisch, M. M., \& Clark, N. A. (1997). The Abundance and Distribution of Waterfowl within Milford Haven after the 'Sea Empress' Oil Spill. BTO Report 173 to the 'Sea Empress' Environmental Evaluation Committee.

Austin, G. E., Read, W. J., Calbrade, N. A., Mellan, H. J., Musgrove, A. J., Skelhorn, A. J., Hearn, R. D., Stroud, D. A., Wotton, S. R., \& Holt, C. A. (2014). Waterbirds in the UK 2011/12: the Wetland Bird Survey. BTO, RSPB and JNCC, in association with WWT. Thetford, U.K.: British Trust for Ornithology, 43 pp.

Bent, E. J. (2000). A review of environmental studies in Milford Haven Waterway 1992 - 2000. Report to MHWESG, 65 pp.

Boyle, D. P. (2012). Grey Seal Breeding Census. Countryside Council for Wales Regional Report CCW/WW/13/1, and WTSWW, 83 pp.

Bullimore, B. (2013) Milford Haven Waterway Environmental Surveillance Group: twenty years of partnership surveillance. Porcupine Marine Natural History Society Newsletter, 34, 69-73.

Camplin, M. (2008). Neyland Dredge Spoil Disposal Environmental Monitoring. Countryside Council for Wales Report, 47 pp.

Cardiff University (2012). An Analysis of Economic Activity Dependent on the Milford Haven Waterway. Report to Milford Haven Port Authority, February 2012, 23 pp.

Carey, D. A., Hayn, M., Germano, J. D., Little, D. I., \& Bullimore, B. (2015). Marine habitat mapping of the Milford Haven Waterway, Wales, UK: comparison of facies mapping and EUNIS Classification for monitoring sediment habitats in an industrialized estuary. Proceedings of the Mesh Atlantic Conference, Special Issue, Journal of Sea Research, 100, 99119. http://dx.doi.org/10.1016/j.seares.2014.09.012

Carls, M. G., Holland, L., Larsen, M., Collier, T. K., Scholz, N. L., \& Incardona, J. P. (2008). Fish embryos are damaged by dissolved PAHs, not oil particles. Aquatic Toxicology 88(2), 121-127.

Cascade Consulting (2011). Yacht Havens Ltd Briefing Note: Neyland Yacht Haven Monitoring Results: Particle Size Analysis, April 2011 Monitoring.

Crump, R. G. (2013). Asterina species in SW. Wales. Porcupine Marine Natural History Society Newsletter, 34, 38-41.

CSEMP (2014). Clean Safe Seas Environmental Monitoring Programme, accessed 2014 via the MERMAN database. www.bodc.ac.uk/projects/uk/merman/

DECC (2013). Sub-national Road Transport Fuel Consumption. Department of Energy and Climate Change, Publication URN: 13D/107, Office of National Statistics, http://www.ons.gov.uk/ (revised June 2013).

DEFRA (2014) Air Quality Data. Department of Environment, Food and Rural Affairs. http://uk-air.defra.gov.uk/data/pahdata

Edwards, A., Garwood, P., \& Kendall M. (1992). The Gann Flat, Dale: thirty years on. Field Studies, 8, 59-75.

Eggleton, J. \& Thomas, K. V. (2004). A review of factors affecting the release and bioavailability of contaminants during sediment disturbance events. Environment International, 30, 973-980.

Elliott, M., \& Griffiths, A. H. (1987). Contamination and effects of hydrocarbons on the Forth ecosystem, Scotland. Proceedings of the Royal Society of Edinburgh, 93B, 327-342.

ETS (2002). Neyland Yacht Haven Dredge Spoil Monitoring Survey. Environmental Tracing Systems Limited Report to Neyland Yacht Haven, 39 pp.

FoE (2010). Pembroke Power Station: Complaint to European Commission. Friends of the Earth Cymru, Cardiff, 27 pp.

Fugro ERT (2012). Investigation into the Source of Hydrocarbons Present in Sediment Samples from Milford Haven Waterway. Report to MHWESG, 43 pp.

Germano \& Associates, Inc. (2013). Sediment-Profile Imaging Survey of Milford Haven Estuary, Wales, UK - May 2012. Report to MHWESG, $50 \mathrm{pp}+$ Appendices.

GTS Subsea (2010). Report on the Sampling of Marine Sediment at Pennar Gut, Milford Haven, August 2010. For Jacobs Engineering Ltd., Seabed Sampling and Analysis by GTS Subsea 16 pp.

Habitats Directive (1992). Council Directive 92/43/EEC on the Conservation of Natural Habitats and of Wild Fauna and Flora, transposed into UK regulations: http://www.opsi.gov.uk/si/si1994/Uksi_19942716_en_1.htm.

Haycock, A. (2013). A Review of the Status of Wetland Birds in the Milford Haven Waterway and Daugleddau Estuary, Report to MHWESG, 123 pp.

Hebog Environmental (Hebog) (2006). Milford Haven Maintenance Dredging Assessment: Biological and Sediment Characterisation Report. HE1632 50 pp. 
Hobbs, G., \& Morgan, C. I. (1992). A Review of the Current State of Environmental Knowledge of the Milford Haven Waterway. Report to the MHWESG by the FSC Research Centre, Pembroke, UK., 140 pp.

Klamer, J. C., Hegeman W. J. M., \& Smedes F. (1990). Comparison of grain size correction procedures for organic micropollutants and heavy metals in marine sediments. Hydrobiologia 208, 213-220.

Krauss, M., \& Wilcke, W. (2002). Sorption strength of persistent organic pollutants in particle-size fractions of urban soils. Soil Science Society of America Journal, 66, 430-437.

Langston, W. J., O’Hara, S. C., Pope, N. D., Davey, M., Shortridge, E., Imamura, M., Harino, H., Kim, A., \& Vane, C. H. (2012a). Bioaccumulation surveillance in Milford Haven Waterway. Environmental Monitoring and Assessment, 184(1), 289-311.

Langston, W. J., Pope, N. D., O’Hara, S., Davey, M., Shortridge, E., Harino, H., \& Vane, C. H. (2012b). Bioaccumulation Surveillance in Milford Haven Waterway, Phase II (2010). Report by the Marine Biological Association to MHWESG, 109 pp.

Lewis, K (2015). The framework for environmental regulation in Wales: Natural Resources Wales speaks with 'one voice' has the statutory voice for nature been silenced? Environmental Law Review, 17 (3), 189-206.

Levell, D., Hobbs, G., Smith, J., \& Law, R. J. (1997) The Effects of the 'Sea Empress' Oil Spill on the subtidal benthos of the Milford Haven Waterway: a Comparison of Survey Data from October 1993 and October 1996. Report to the Environment Agency by OPRU/CordaH no. OPRU/22/97.

Little, D. I. (2009). Sediment Contaminants and Transport Review. Report to MHWESG, 414 pp.

Little, D. I., Howells, S. E., Abbiss, T. P., \& Rostron, D. (1987). Some factors affecting the fate of estuarine sediment hydrocarbons and trace metals in Milford Haven. In: P. J. Coughtrey, M. H. Martin, and M. H. Unsworth (Eds.) Pollutant Transport and Fate in Ecosystems (pp. 55-87). Oxford: Blackwell.

Little, D. I., \& McLaren, P. (1989). Sediment and contaminant transport in Milford Haven. In B. Dicks (Ed.), Ecological Impacts of the Oil Industry (pp. 203-234). Chichester and New York: John Wiley and Sons.

Little, D. I., \& Little, A. E. (1991). Estuarine oil spill effects in the context of dispersant use changes. Proceedings 1991 International Oil Spill Conference, March 4-7, 1991, San Diego, California.

Little, D. I., \& Bullimore, B. (2015). Discussion of: McLaren, P., Sediment trend analysis $\left(\mathrm{STA}^{\circledR}\right)$ : kinematic $v s$. dynamic modeling, Journal of Coastal Research, 2014, 30(3), 429-437. Journal of Coastal Research 31(1), 224-232. http://dx.doi.org/10.2112/JCOASTRES-D-14-00108.1

Little, D. I., Galperin, Y., Bullimore, B. \& Camplin, M. (2015). Environmental forensics evaluation of sources of sediment hydrocarbon contamination in Milford Haven Waterway. Environ. Sci.: Processes and Impacts, 17, 398-420. http://dx.doi.org/10.1039/c4em00522h

Little, D. I., \& Galperin, Y. (in press). The assessment of hydrocarbon contamination in contrasting sedimentary environments. In: K. Heimann, O. P. Karthikeyan and S. S. Muthu (Eds.), Biodegradation and Bioconversion of Hydrocarbons: Research Advances and Recent Developments. ISBN: 978-981-10-0199-4, Springer-Verlag Singapore.

Longdin and Browning (Surveys) Limited (2002). Milford Haven Sediment Plume Tracking, 2002 Survey Report H4776, 16 $\mathrm{pp}+9$ Appendices.

McLaren, P., \& Little, D. I. (1987). The effects of sediment transport on contaminant dispersal: an example from Milford Haven. Mar. Poll. Bull. 18(11), 586-594.

MHPA (2011). Milford Haven Port Authority: Dredging Strategy Document, Revision 1, Anthony Bates Partnership Limited, $66 \mathrm{pp}$.

Morgan, C. I., King, G. A. D., \& Evans, S. B. (1996). Environmental management in Milford Haven: an integrated approach. In: Jones, Healy and Williams (Eds.), Studies in European Coastal Management, Samara Publishing Limited, Cardigan, ISBN 1873692072.

Musgrove, A. J., Collier, M. P., Banks, A. N., Calbrade, N. A., Hearn, R. D., \& Austin, G. E. (2007). Waterbirds in the UK 2005-06: Wetland Bird Survey. BTO, WWT, RSPB and JNCC, Thetford, U.K: British Trust for Ornithology 207 pp.

Nelson-Smith, A. (1965). Marine biology of Milford Haven: the physical environment. Field Studies, 2, 155-188.

Newell, R. C., Seiderer, L. J., \& Hitchcock, D. R. (1998). The impact of dredging works in coastal waters: a review of the sensitivity to disturbance and subsequent recovery of biological resources on the seabed. Oceanogr. Mar. Biol. Ann. Rev. 36, 127-178.

NMMP (2004). UK National Marine Monitoring Programme - Second Report for 1999-2001. CEFAS, ISBN 0907545203.

OSPAR (2009a). OSPAR Coordinated Environmental Monitoring Programme (CEMP), OSPAR reference number: 2009-1.

OSPAR (2009b). Agreement on CEMP Assessment Criteria for the QSR 2010, OSPAR agreement: 2009-2.

OSPAR (2009c). Background Document on CEMP Assessment Criteria for the QSR 2010, Monitoring and Assessment Series.

PCNPA (2014). Daugleddau Estuary and Milford Haven Waterway Annual Surveillance of Summer Shelduck Populations, Pembrokeshire Coast National Park Authority Report to MHWESG, 42 pp.

Prater, A. J. (1981). Estuary Birds of Britain and Ireland, T. and A. D. Poyser Ltd., 440 pp.

Rostron, D. M., Little, D. I., \& Howells, S. E. (1986). A study of the sediments and communities in Milford Haven, Wales. Oil and Chemical Pollution, 3, 131-166.

RWE npower (2007). Proposed Pembroke Power Station Consolidated Environmental Statement (internet fragments accessed 2013, originally available at http://www.marinemanagement.org.uk/works/environmental_pembroke.htm but now archived).

Van Straaten, L. M. J., \& Kuenen, P. H. (1958). Tidal action as a cause of clay accumulation. J. Sed. Pet., 28(4), 406-413.

Warwick, R. M. (2006). Review of Benthic and Intertidal Sediment Macrofauna Data, and Development of a Surveillance Programme. Report to MHWESG, 105 pp.

Warwick, R. M. (2007). Analysis, Comparison and Interpretation of Macrobenthic and Seabed Sediment Data for St Bride's Bay, South Hook LNG and Dragon LNG, 2006-2007. Report to Milford Haven Port Authority, 42 pp + Appendices. 